Claremont Colleges

Scholarship@ Claremont

WM Keck Science Faculty Papers

W.M. Keck Science Department

$1-1-2012$

\title{
Post-speleogenetic Biogenic Modification of Gomantong Caves, Sabah, Borneo
}

Joyce Lundberg

Carleton University

Donald A. McFarlane

Claremont McKenna College; Pitzer College; Scripps College

\section{Recommended Citation}

Lundberg, J. and McFarlane, D.A. (2012). "Post-speleogenetic biogenic modification of Gomantong Caves, Sabah, Borneo." International Journal of Speleology.

This Article is brought to you for free and open access by the W.M. Keck Science Department at Scholarship @ Claremont. It has been accepted for inclusion in WM Keck Science Faculty Papers by an authorized administrator of Scholarship @ Claremont. For more information, please contact scholarship@cuc.claremont.edu. 


\title{
Post-speleogenetic biogenic modification of Gomantong Caves, Sabah, Borneo
}

\author{
Joyce Lundberg$^{1}$ and Donald McFarlane ${ }^{2}$ \\ ${ }^{1}$ Department of Geography and Environmental Studies, Carleton University, Ottawa ON K1S 5B6 \\ CANADA. joyce_lundberg@carleton.ca \\ ${ }^{3}$ W. M. Keck Science Center, The Claremont Colleges, Claremont CA 91711 USA. \\ dmcfarla@jsd.claremont.edu
}

\begin{abstract}
The Gomantong cave system of eastern Sabah, Malaysia, is well-known as an important site for the harvesting of edible bird's-nests and, more recently, as a tourist attraction. Although the biology of the Gomantong system has been repeatedly studied, very little work has been done of the geomorphology. Here we report on the impact of geobiological modification in the development of the modern aspect of the cave, an important but little recognized feature of tropical caves. Basic modelling of the metabolic outputs from bats and birds $\left(\mathrm{CO}_{2}, \mathrm{H}_{2} \mathrm{O}\right.$, heat) reveals that post-speleogenetic biogenic corrosion can erode bedrock by between $\sim 3.0 \mathrm{~mm} / \mathrm{ka}(1 \mathrm{~m} / \sim 300 \mathrm{ka})$ and $\sim 4.6 \mathrm{~mm} / \mathrm{ka}(1 \mathrm{~m} / \sim 200 \mathrm{ka})$. Modelling at high bat densities yields corrosion rates of $\sim 34 \mathrm{~mm} / \mathrm{ka}$ (or $1 \mathrm{~m} / \sim 30 \mathrm{ka}$ ). Sub-aerial corrosion creates a previously undescribed speleological feature, the apse-flute, semicircular in cross-section, $\sim 80 \mathrm{~cm}$ wide, vertical regardless of rock properties, developing in parallel but apparently completely independently, and often unbroken from roof to floor. They end at a blind hemi-spherical top with no extraneous water source. Half-dome ceiling conch pockets are remnants of previous apse-fluting. Sub-cutaneous corrosion creates the floor-level guano notch formed by organic acid dissolution of bedrock in contact with guano. Speleogenetic assessment suggests that as much as $70-95 \%$ of the total volume of the modern cave may have been opened by direct subaerial biogenic dissolution and biogenically-induced collapse, and by subcutaneous removal of limestone, over a timescale of 1-2 Ma.
\end{abstract}

Keywords: bio-geomorphology, biogenic corrosion, apse flute, bat, swiftlet.

\section{Introduction}

Gomantong Hill $\left(5.51^{\circ} \mathrm{N}, 118.06^{\circ} \mathrm{E}\right)$ is an isolated limestone outcrop on the flood plain of the Menungal River (tributary of the Kinabatangan river), some $30 \mathrm{~km}$ south of Sandakan, Sabah, north-west Borneo (Fig. 1), penetrated by an interconnected series of large caverns. The caves are amongst the most famous in southeast Asia, having been the focus of the edible birds' nest industry for several centuries (Francis, 1987; Hobbs, 2004). However, other than a short pioneering study by Wilford (1964), the caves have never been studied except in the context of this industry (e.g., Koon and Cranbrook, 2002; Hobbs, 2004).

The caves are located within the 3000 hectare Gomantong Forest Reserve. The tourist cave, called Simut Hitam (or Black Cave, Fig. 2) with its huge colonies of black-nest swiftlets
(Aerodramus (Collocalia) maximus) swiftlets, is the more famous site for bird nest collecting. This is the smaller of the two caves by length but it has the larger volume passages. The upper level, less accessible cave, called Simud Puteh (White Cave), has an entrance $\sim 85 \mathrm{~m}$ above the main level of Simud Hitam (Wilford, 1964). Some of the other passages of Simud Puteh also open at high level into Simud Hitam, so that technically, the Gomantong "caves" are a single cave system. The basic cave form is relatively straightforward, developed along bedding planes and steeply inclined joints. The bedding plane passages are typical phreatic dip tubes, elliptical or round in cross section with scalloped walls and ceilings, the dip as shown in Wilford's (1964) diagrams at $\sim 20^{\circ}$, but variable. The joint passages are high (e.g., Wilford, 1964, quotes one estimated at 137 m) with a pointed arch-shaped cross section. 
Fig. 1. Location of Gomantong Caves, Sabah.

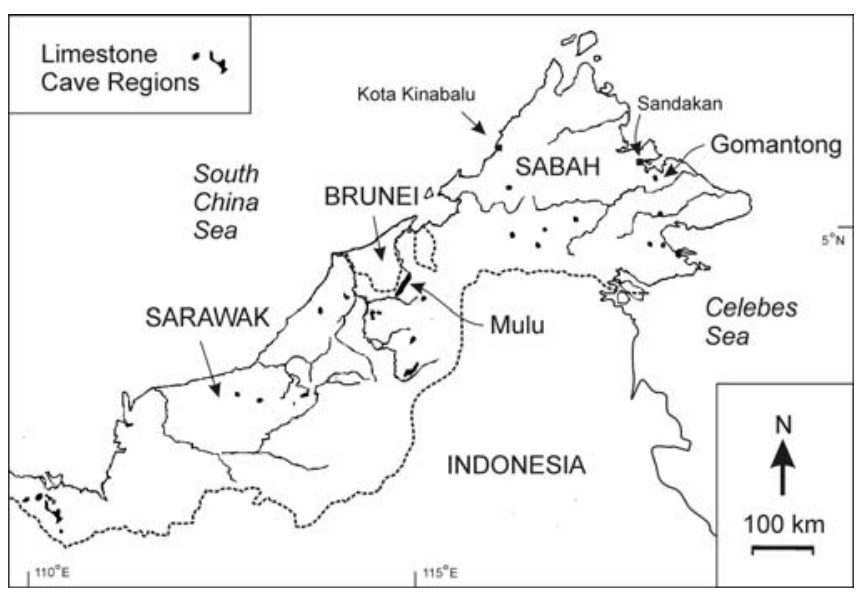

The cave houses great numbers of organisms, including bats and swiftlets, along with a diverse and dense guano-based invertebrate community. The bat population, which has never been rigorously assessed, is in the order of $10^{6}$ individuals (Abdullah et al., 2005; Couzens, 2008, p.85; Kingston, 2010). Twelve species of bat are reported by Abdullah et al. (2007), the majority being wrinkle-lipped bats (Chaerephon plicata), the population of which Abdullah et al. (2005) estimate to be at least 600,000 . The other common species recorded at Gomantong include Hipposideros cervinus, Rhinolophus philippinensis (Abdullah et al., 2005), Rhinolophus borneenis, Rhinolophus creaghi (Csorba et al., 2003), and Myotis gomantongensis (Francis and Hill, 1998). The remaining six of the twelve species referred to in Abdullah et al. (2007) are not yet known (to us), but population

\subsection{Geological background}

Gomantong Hill is the largest of a series of steep-sided tower-like limestone outcrops in the Lower Kinabatangan area. The caves are formed in the Gomantong Limestone, dated by foraminiferal assemblages to uppermost Oligocene (Chattian) to lower Miocene (Burdigalian) age ( 28-16 Ma: Noad, 2001; Hutchinson, 2005). The Gomantong Limestones lie unconformably on, and sometimes interfinger with turbidites (sandstones and shales) of the Oligocene Labang Formation. They were deposited as a narrow carbonate platform in an open shelf environment next to an east-west sizes are likely to be small and not relevant to our current study.

The swift population is the same order of magnitude (e.g., Tompkins, 1999, and Tompkins and Clayton, 1999, quote 1.5 million), but only two species occur: the black-nest swiftlet (in the main tourist cave) Aerodramus maximus and the white-nest swiftlet (in the upper level cave) Aerodramus fuciphagus.

Bats generally occupy separate niches inside the cave, the bats in the darkest and most remote recesses according to Chasen (1931a, 1931b), who also notes that large sections of the caves are unoccupied by either bat or bird. We observed that, although birds and bats do not intermingle freely, they may roost within just a metre or so. Since the swiftlets roost in the cave between dusk and dawn, and the bats roost in the same general areas during daylight hours, roost sites host a significant biomass 24 hours a day.

In this paper we document some of the features, from Simud Hitam (the lower cave), of post-speleogenetic modification by biogenic corrosion that make this cave unique and demonstrate that this process can be substantial. The only mention we have found in the literature of anything comparable is Piccini et al. (2007) who briefly mention that some of the caves of Mexico show substantial biogenic corrosion that disguises the original shapes of the caves, including domes due to condensation corrosion of the ceiling.

trending shoreline. They are mainly coraldominated fore-reef and open marine facies but include a variety of facies varying from open marine marls to shore-attached reefal deposits. Although deformed, steeply-dipping and sometimes overturned in the Late Pliocene ( 3-2 Ma; Hutchinson, 2005), the carbonates are well preserved and show little diagenetic alteration (Collins et al., 2003). Exposures are limited to isolated outcrops dotted around on the flood plain of the river. The Gomantong Limestone is typically a compact detrital grey limestone, sometimes recrystallised, containing abundant large benthic foraminifera and other fauna. At the Gomantong Caves, the outcrop is $\sim 300 \mathrm{~m}$ in thickness (Noad, 2001). Gomantong Hill is a synclinal feature, with 
dips of $\sim 5-25^{\circ}$ (Noad, 2001), and in the region of the cave the dip is $20-30^{\circ}$ to the NW (Wilford, 1964). The pattern of jointing is near-vertical and radial - typical of a syncline - trending $\mathrm{N}$ and

\subsection{Geomorphological and speleological background}

Very little literature is available on the geomorphology or speleology of this region, the majority of attention on caves of Borneo being reserved for the Mulu region of Sarawak. The geomorphological history includes uplift, compression and folding in the Late Pliocene $(\sim 3-2$ Ma), followed sometime later by downcutting. Francis (1987) shows the top of Gomantong Hill at $221 \mathrm{~m}$ asl, so the upper entrances to the upper cave passages open into the top of the hill at around $200 \mathrm{~m}$ asl. Thus total downcutting at Gomantong, as indicated by the difference in level between the floor of upper cave and the floor of lower cave, is around 150 $\mathrm{m}$.

Estimates of the rate of landform development for the Mulu region (390 $\mathrm{km}$ to the south west of Gomantong) suggest that most of the features apparent today have developed within the Pleistocene. Sweeting et al. (1980) interpreted the early erosion surfaces on Gunung Api and Benarat to be early Pleistocene, but no similar erosion surfaces can be seen in the Gomantong district. Some of the events have been extremely rapid; e.g. Rose (1984) suggests that the gorge of River Melinau in Mulu may have been cut largely during the Holocene (on the evidence of marine isotope stage 2-4 high level terrace deposits). Farrant et al. (1995) estimate Quaternary uplift rates (from electron spin resonance, paleomagnetic, and uraniumseries dating of sediments on cave levels) for the Mulu region of $0.19 \mathrm{~m} / \mathrm{ka}$. If this rate applies also to Gomantong Hill then uplift began $~ 1 \mathrm{Ma}$ and the whole of the surface landscape evolution has occurred within the Pleistocene.

The Gomantong caves are essentially large phreatic tubes. They are similar to the Mulu region caves only in that speleogenesis is controlled by strike and dip (Waltham and Brook, 1980), but they differ from the Mulu caves in that they are largely relict and have only
NE in the region of the caves. The cliff-line of Simud Hitam entrance follows one of the major faults

(Wilford,

1964).

a little vadose development and no active river passages. They are similar to some of the abandoned high level tunnels of Mulu that follow bedding planes, with dip-oriented passages and phreatic risers (Waltham, 2004). Speleogenesis probably started soon after uplift some 2-3 Ma. Rapid uplift of the landscape caused rapid draining of cave, as evidenced by the lack of vadose incision features, so the original phreatic tube form has remained intact. Many are simple dip and lift tubes with clear asymmetric current scallops on the walls and ceilings, but in the large passages postspeleogenetic modification often obscures the original form.

In this paper we document the nature and extent of this post-speleogenetic biogenic modification of the passages. The Gomantong caves are ideal for this purpose because their original phreatic form is quite simple and still clear in places. The absence of bat/bird colonization in some parts and therefore the absence of biogenic alteration of the passage allows us to compare the modified sections with the unmodified sections. We also model the potential impact on dissolution from metabolism of the birds and bats. We have previously modeled, for bellholes in a cave in Jamaica (Lundberg and McFarlane, 2007), the impact of bat populations on heat, moisture, and $\mathrm{CO}_{2}$ output. The situation in Gomantong is more complicated than the bellholes, since it involves both bats and birds, and since the cave morphology is complex. However, we have successfully modeled the relatively simple geometry of the central aven and demonstrate how the presence of organisms can feasibly modify the roof in a reasonable time frame.

Substantial biogenic modification of tropical limestone caves appears to be a widespread phenomenon - we have examined examples as far afield as Windsor Great Cave and Thatchfield Cave, Jamaica - but one which has been little recognized. It represents an interesting example of niche modification (Dawkins, 2004) that can significantly obscure or confuse speleogenetic interpretations. 
Fig. 2. Cave survey, Simud Hitam, Gomantong. This is based on the survey reproduced in Wilford (1964), with added structural elements (red dashed lines). Cross section B-B' is also based on Wilford (1964), with corrections. Cross sections A-A' and C-C' are constructed from our low grade field survey and data in Wilford (1964). The upper case letters mark our field locations.

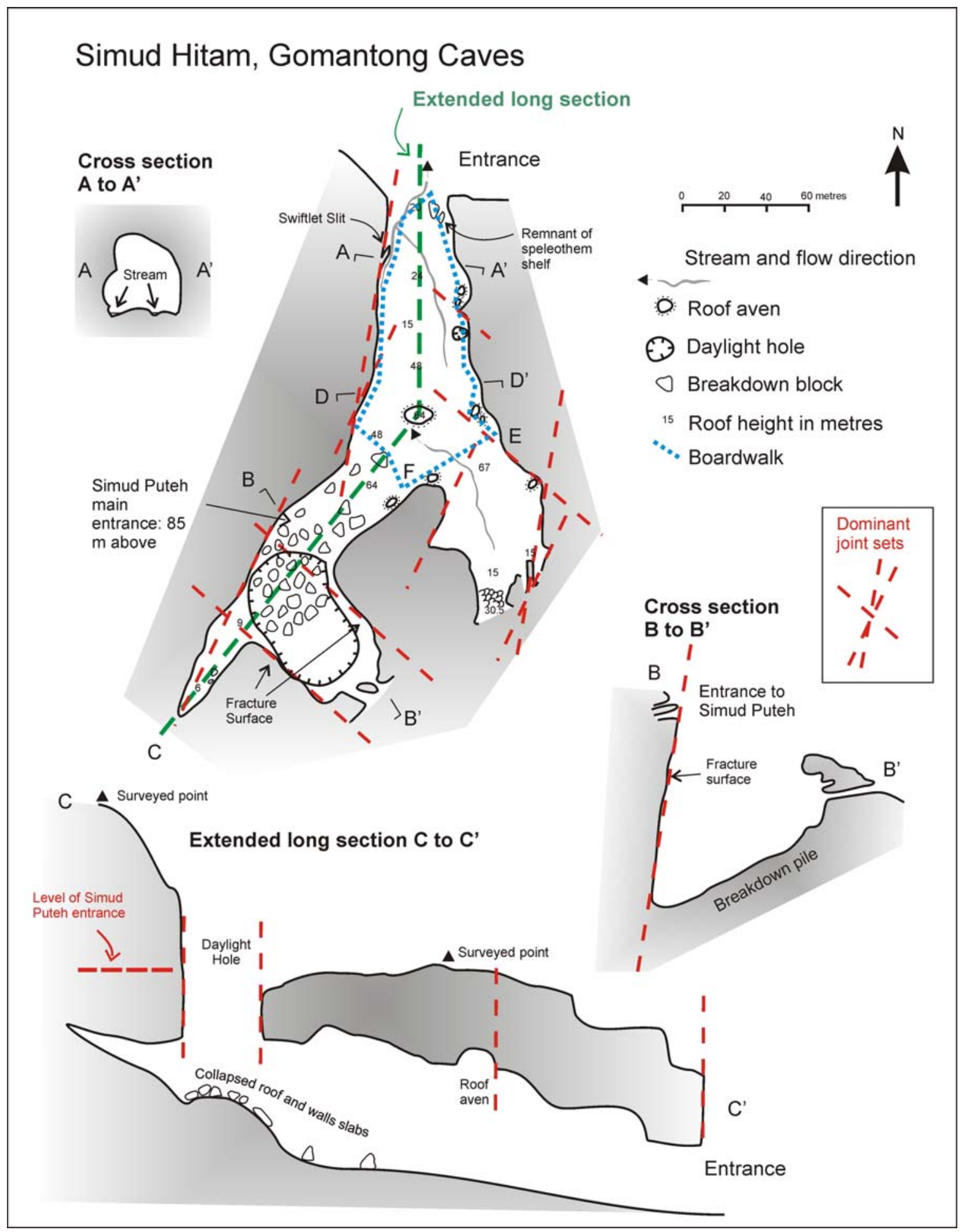


Fig 3. Roof to floor apse flutes close to location D on the survey. This view also shows, at centre right, one of the upper level phreatic tubes, and, at the tourist boardwalk level, an undercut guano notch.

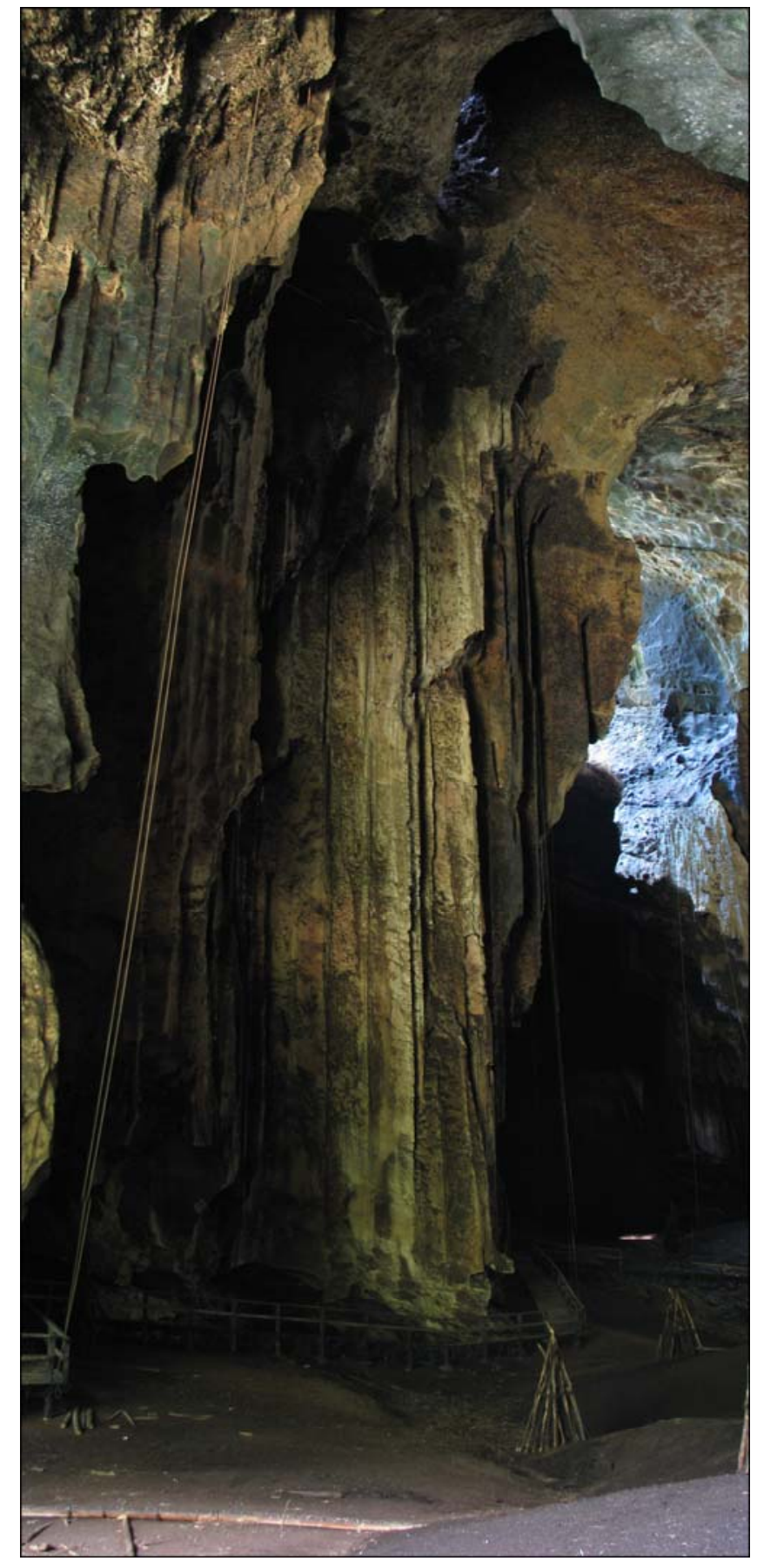

\section{Methods}

Field work was carried out during two visits to the caves, in July of 2007 and again in August of 2008. Our main focus was Simud Hitam. The cave was not re-surveyed (the survey published in Wilford, 1964, was used as a base map), but detailed surveys were done of features of interest, using standard compass and clinometer cave survey techniques, distances measured with a Leica Geosystems Laser Rangefinder. As a basis for modeling, densities of birds and bats were recorded in the field photographically, for later analysis. Bat counts, swiftlet nest counts, and area calculations were performed on calibrated photographs using Image J software (http://rsbweb.nih.gov/ij/). Bat species could not always be identified from photographs because the ceilings were too high for our electronic flashes. Photography depended largely on long exposures of the natural daylight, thus image quality of the photographs varies greatly depending on location within the cave. Rock temperature was measured using an infra-red remote thermometer (brand name- Raytek ST60: spatial precision $13.3 \mathrm{~cm}$ at 4 $\mathrm{m}$; thermal precision $\pm 0.27^{\circ} \mathrm{C} 2$ sigma, calibrated on limestone at $33{ }^{\circ} \mathrm{C}$ against NIST certified precision thermometer).

\section{Geomorphology Results}

Wilford (1964) reproduces the survey that was prepared in the 1930s, and briefly describes Simud Hitam (Fig. 2): it is mainly developed along bedding planes; the main passage divides, the one to the SE following the dip, and the one to the SW following the bedding plane; and small tube-like passages can be seen near the roof. We observed that some of the original phreatic tube can still be seen close to the main entrance, but most parts of the passage have been altered from the basic phreatic form and now show dramatically fluted vertical walls, high ceilings and various low-level sub-horizontal notches. Several quasi-planar surfaces can be seen that follow major joints: these we show on Figure 2 with dashed lines; for example, the large collapse feature close to the southwestern limit of the cave is clearly delimited by joint planes, as is the straight wall of section BB'.

The biogenic post-speleogenetic passage modifications can be classified as: 1 . sub-aerial (walls and ceilings); and 2. sub-cutaneous (beneath the guano-sediment fill, now exposed through settling and erosion). Note that minor non-biogenic post-speleogenetic modification in the form of condensation corrosion hollows can be seen. close to the entrance. 


\subsection{Sub-aerial features}

The sub-aerial modifications include wall flutes and hemi-spherical wall and ceiling pockets. These forms are genetically interconnected and thus are described together. These are so reminiscent of vaulted cathedrals that we have found it useful to employ architectural terms to describe and name them.

The form that immediately strikes the visitor to Simud Hitam is the vertical flute of semi-circular cross section that sometimes reaches from floor to roof in a single unbroken line (Fig. 3). It is important to note that these flutes are inherently different from any other flute. The word "flute" normally implies some sort of channel flow and an upstream source of fluid, either direct rainfall in the case of nonHortonian rills such as rillenkarren or accumulated discharge in normal (Hortonian) drainage channels. The flutes of Gomantong have no upstream source of fluid.

We have called these "apse flutes" (an apse being a semicircular recess covered with a hemispherical semi-dome) and the top is the "conch" (the architectural term for the semidome that tops small apses) (Fig. 4; the location of examples is indicated by reference to the upper-case letters on the survey, Fig. 2). The ceiling has many rounded pockets that mirror the shape of the tops of the flutes. Some, the ones that are close to the wall of flutes, are obviously the tops of flutes whose base has been eroded away. Others, further away from the wall of flutes, are just the semi-spherical hollows, so we have called these "conch pockets". Where two flutes intersect the vertical sharp edge between them is the equivalent of the raised edge separating flutings in a Doric column, called the "arris". In cross section, the arris forms a "cusp" where the two arcs of the semi-circular crosssection meet. In some cases, the arris between intersecting flutes is complex and large, creating a type of remnant "buttress". Flutes may be (rarely) isolated or may develop in series. Where several flutes cut into the wall more than others a "fluted bay" develops in the line of the cave wall and the emergent form is a "fluted column" (Fig. 4).
In cross-section apse flutes are an arc of a circle. A complete circle would be visible only if developed in the roof (like bellholes). The majority are semicircular or less. Juxtaposed flutes seem to have no influence on each other; lateral extension of two parallel flutes may cause the two arcs to intercept, creating narrow rock flakes, often with lacy holes where the inter-flute rock membrane has been breached. Where three flutes intersect, it is unlikely that all will enlarge at the same rate; thus one will be gradually reduced in width, such that its cross-section is a very small part of the original arc and its definition as an independent flute is lost. Widths of flutes were measured in the field and from photographs, choosing as far as possible only those flutes with a full semi-circular cross section. They range from $\sim 50 \mathrm{~cm}$ up to $\sim 120 \mathrm{~cm}$, the average being $81( \pm 24) \mathrm{cm}$. The lengths of flutes vary with passage height and with stage of development. Many flutes show some diminution in depth and width downslope and may peter out before they reach the floor (as is typical of decantation flutes where the fluid loses aggressivity with distance from source however, in this case, no obvious source of fluid can be seen).

The tops of the apse flutes are often a semi-dome or else just the flat cap of a bedding surface. However, the flute-wall to flute-top junction is rounded with no evidence of a sharp break of slope and no bedding plane recess or line of joint (i.e., there is no evidence for any point or linear source of water). Sometimes the extending flutes reach a more resistant bedding surface that temporarily halts the extension. The horizontal surface does not remain intact for long; another generation of conch pockets starts to cut upwards into it, leaving cornices in the vertical profile. Conch pockets may superficially resemble classic current scalloping (e.g., see Mihevc et al., 2004), but the phreatic scallops are asymmetric and approximately $10-15 \mathrm{~cm}$ in length, while the conch pockets are symmetrical and larger, some 40-80 $\mathrm{cm}$ in diameter, and the cusps have an acute angle. Conch pockets may also superficially resemble normal ceiling pockets of phreatic origin (e.g., see Slabe, 1995) but conch pockets never show the deep pocketin-pocket forms that occur from turbulent 
phreatic flow. The conches and conch pockets appear to be the preferred sites for swiftlet nests (Fig. 5, 7).

The most significant features of the apse flutes and conch pockets is that they are blind, they extend upwards into the roofs of caves, they are vertical regardless of lithological variation, stratigraphic dip, or ceiling gradient, and they have no association with fractures or feedwater routes.

Fig. 4. Features of sub-aerial biogenic modification: form and terminology for the apse flutes (the rattan ladder is part of the nest collection gear).
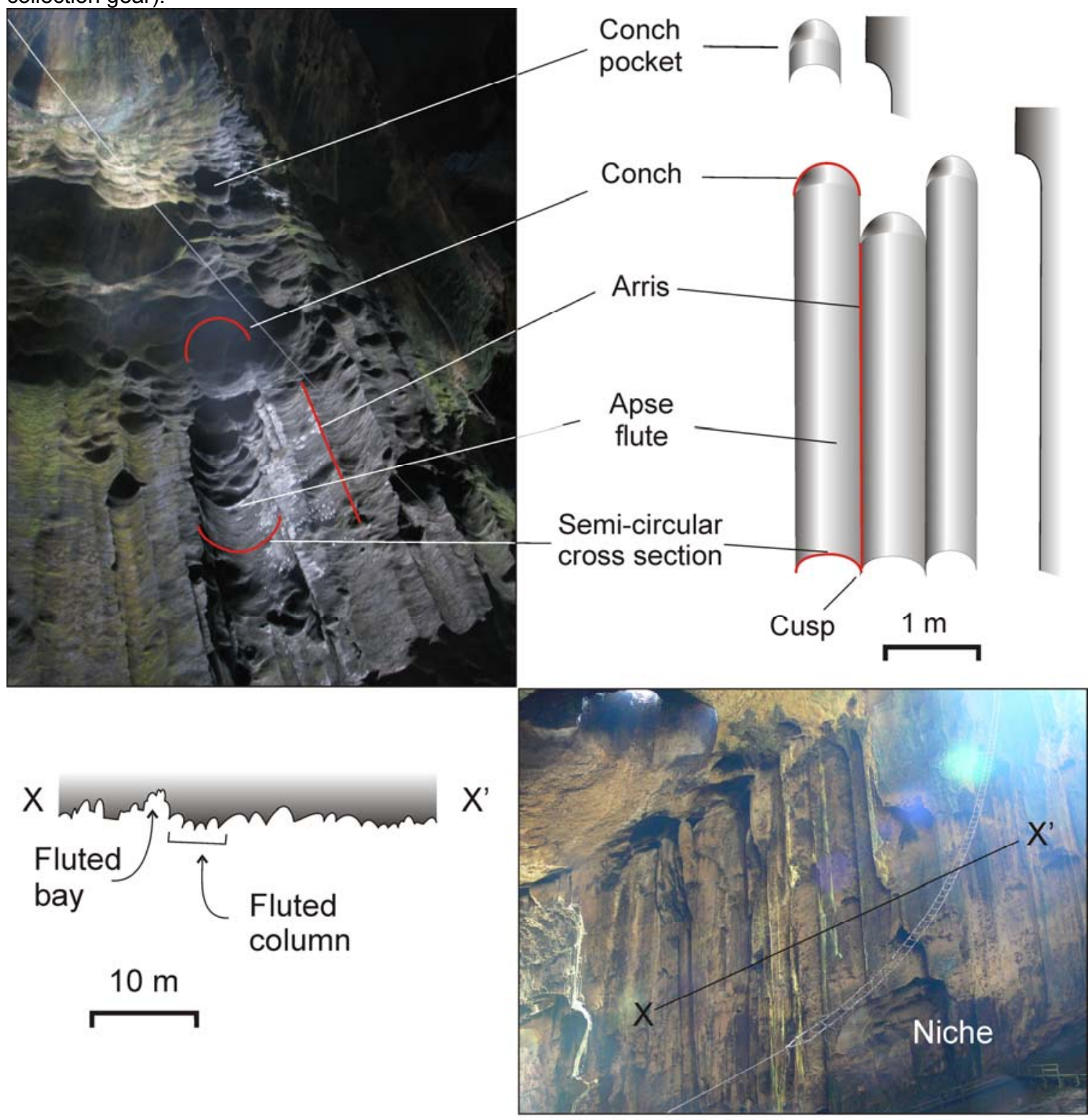

\subsubsection{Development}

Wall profile $15 \mathrm{~m}$ up side of wall at location A to $D^{\prime}$

For the majority of apse flutes the morphology indicates that they extend vertically into the cave ceiling at the same time as laterally into the cave wall. New flutes start at lower levels and several generations of flutes can be seen extending upwards en echelon. Fig. 5 shows an example from the southeastern wall close to position E on the survey. (This figure also shows an example of floor-level undercut notch - discussed below). Each generation cuts vertically and laterally, subsequent generations starting at the base of older flutes; the result is a series of inverted steps going up to ceiling, the flutes forming the risers and the ceiling hollows the (anti)steps. 
Fig. 5. A. Example of apse flute formation from wall close to position south of $E$ on plan. At least three generations of apse flutes can be seen, each apparently progressing up the wall by a form of headward erosion. This image also shows undercut niche from sub-guano corrosion. B. Side view and plan views at different elevations.

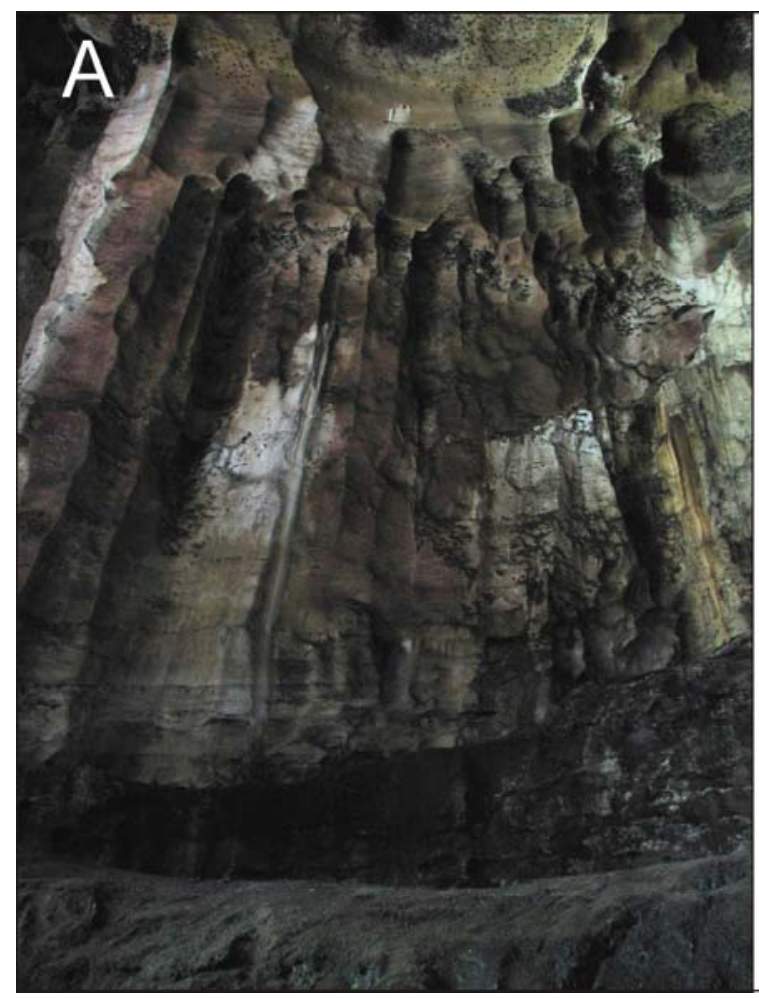

Evidence for this mode of development can also be seen in the form of the roof avens, which are not the typical vadose cave aven (sometimes called domepit - see Lauritzen and Lundberg, 2000) that tapers towards a point in the roof from which water emerges (the usual source of solvent). Instead the avens here have vertical sides and a fretted plan. The sides can be seen to have the vertical lines of the apse flutes, and the aven roof is marked by conch pockets. Some of the avens have punched through the roof to create small daylight holes where vertically extending flutes meet the fretting of surface karren to create an interestingly lacy morphology (Fig. 6). Note that the huge daylight hole at the southwest corner of the cave (Fig. 2, section B-B') is not from fluting - or at least not from fluting alone - it is a standard cave collapse with a large pile of collapse blocks at its base.

The simple flutes that extend upwards are in the majority. However, some examples can be seen of a new generation of flutes starting in the middle of an old flute at some random position up the wall, where a conch pocket cuts laterally into an older surface. These do not start from

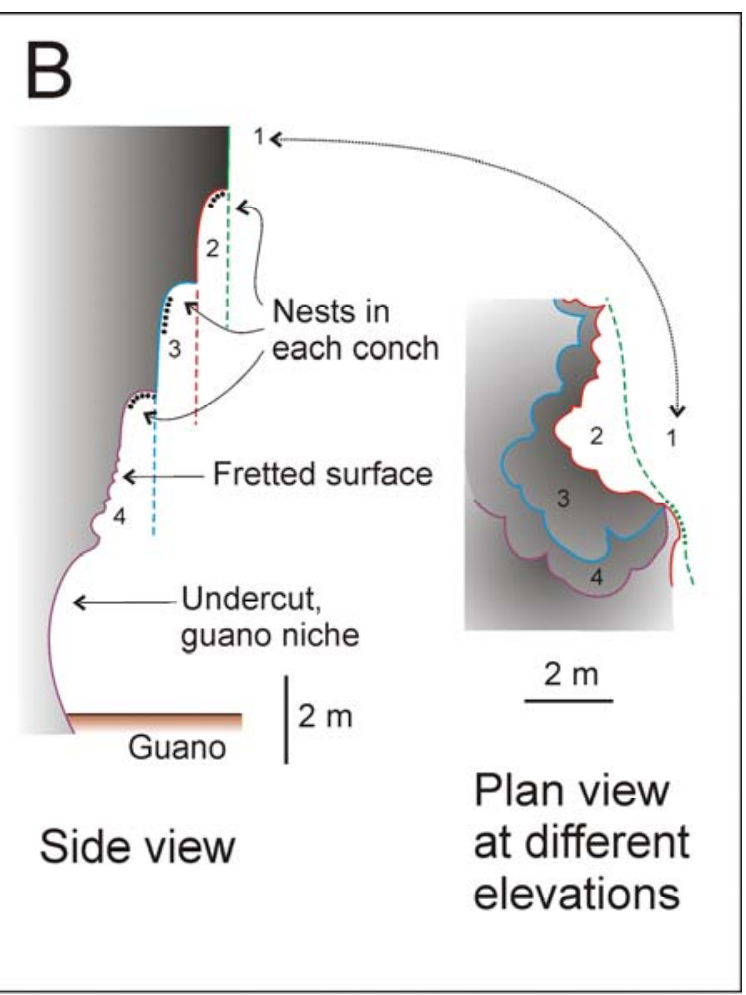

Fig. 6. Daylight holes (between locations $E$ and $F$ on survey) created where vertically extending flutes meet the fretting of surface karren resulting in a delicately lacy texture that is quite distinct from the normal cave daylight hole created by collapse. Note rattan ladder for scale.

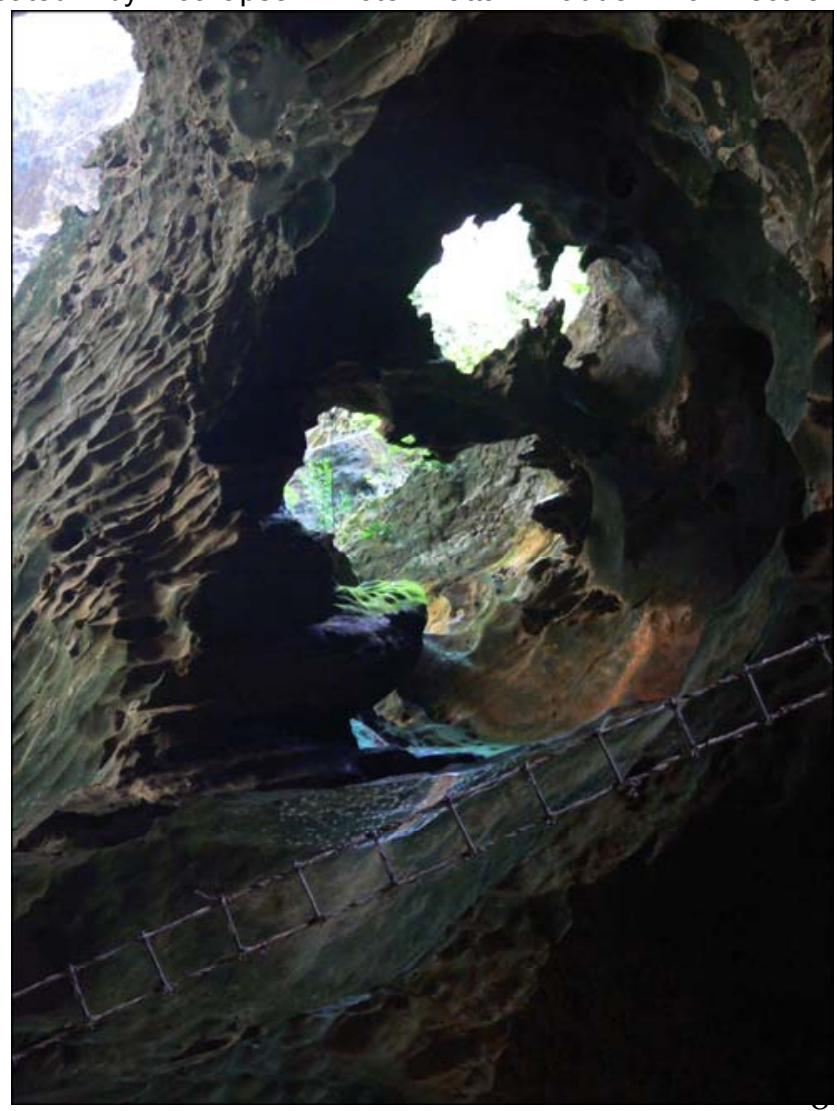


lower levels and work upwards; they start in the middle and extend both vertically upwards and downwards (Fig. 7).

The ceiling conch pockets have a similar rounded form to the apse flute tops and generally appear to be the remnant form of many generations of flutes having cut upwards into the ceiling and laterally into the walls. These can be seen in the photograph (Fig. 8) of the entrance zone ceiling where the original phreatically- scalloped roof is being systematically eaten up by the advancing fluting. (This image also shows some large wall niches or hollows called "air scallops”, some $4 \mathrm{~m}$ tall, $3 \mathrm{~m}$ wide, and $1 \mathrm{~m}$ deep. These are created by normal cave entrance condensation corrosion - see Ford and Williams, 2007, p. 259 - and represent a minor form of nonbiogenic post-speleogenetic passage modification that occurs only in the zone $\sim 15-30 \mathrm{~m}$ from the entrance).

Fig. 7. A new generation of apse flute beginning to form halfway up the wall. The earlier generations can be seen progressively up the wall reaching to the ceiling. The side and plan views show the earlier wall profile, which has a rougher, more crusted texture than the newer surfaces. Swiftlet nests can be seen in each conch.

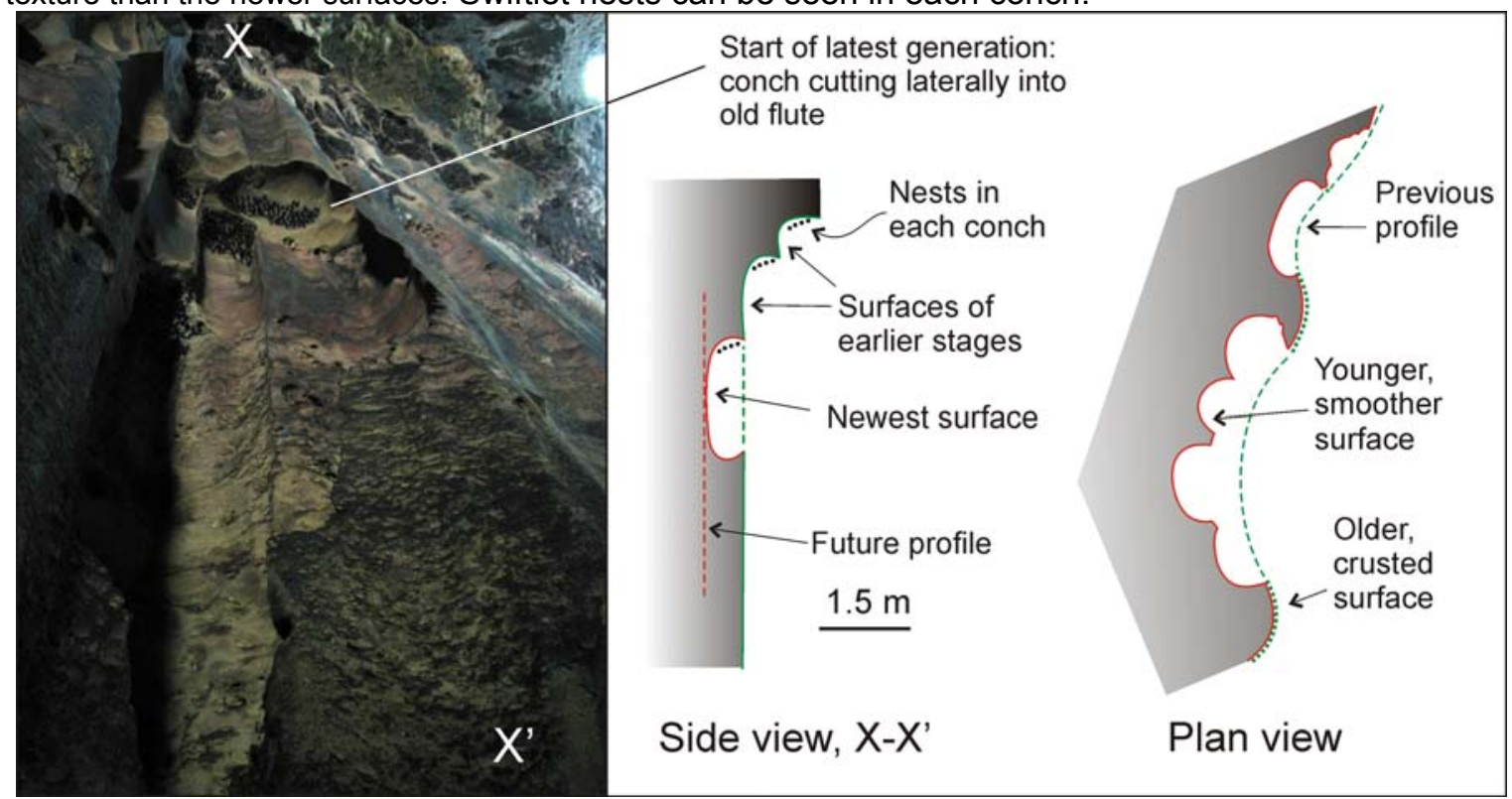

Although no joint lines can be seen in the tops of the apse flutes, in some examples, the development of the flutes in plan view indicates a tendency for lines of flutes to develop by headward extension along joints. One such example is the feature we have called "Swiftlet Slit”, just to the north of A on the survey. The person in Fig. 9A looking up to the roof of the narrow re-entrant lined with apse flutes has the view shown in Fig. 9B, photographed vertically from eye level up to the roof of the slit. The roof is lined with swiftlet nests and roosting bats. The flutes can be seen to the right and the original phreatically-scalloped roof to the left. The morphology is elucidated in the cross section (Figure 9C, drawn, for consistency, from the same point of view as the section A-A' on the survey) and plan view (Fig. 9D). Figure 9E illustrates the sequence of development of the flutes by headward extension. The slice of cave wall left is only a metre or so wide. In time this will separate completely and fall into the passage exposing the relatively straight fluted interior of the slit and expanding the passage width by a couple of metres. This process can be seen at several stages in other parts of the cave. Another example is shown in Fig. 10. This process of extension along a joint is not because the joint provides water - rather it is because the angle of joint and cave wall is so acute that pressure release opens the joint slightly, which then provides an attractive site for nesting. 
Fig. 8. The original phreatically-scalloped ceiling is being eaten up by progressive flute development (middle of section A-A' on plan). The phreatic scallops can be seen to the right - marked " $s$ ". Various types of wall pocket can be seen, the ceiling conch pockets marked " $c p$ ". The wall niches at floor level are condensation corrosion hollows - marked " $c c$ ".

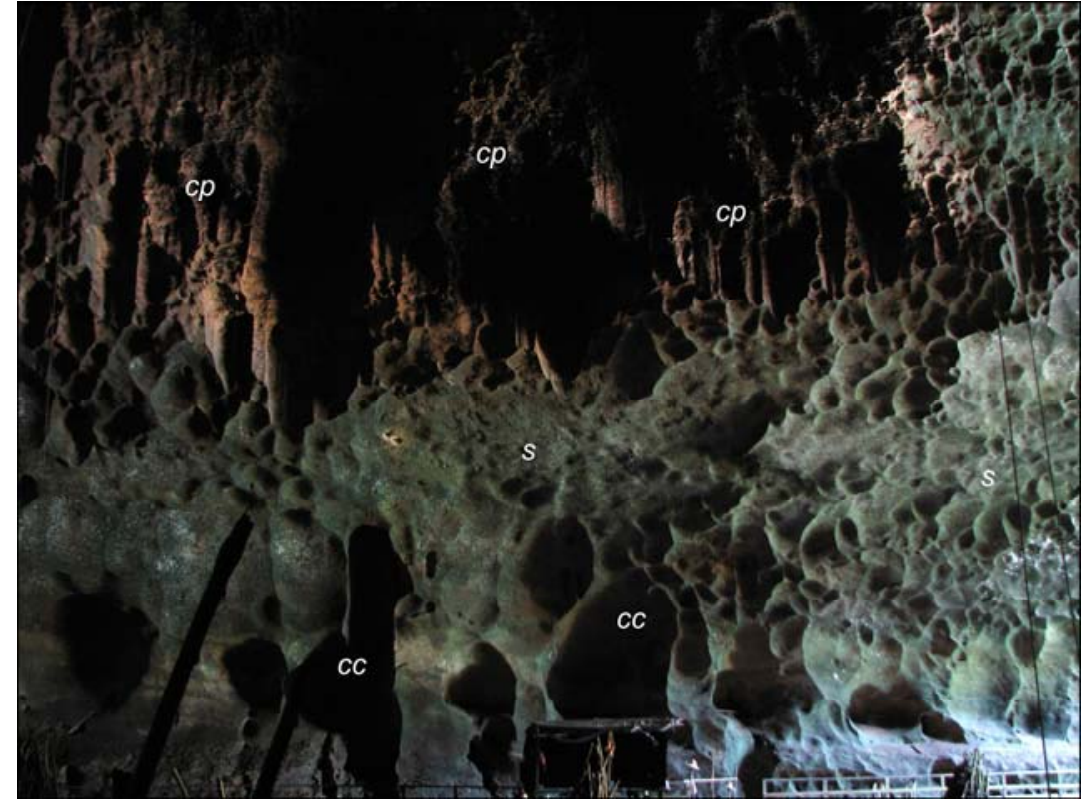

Fig. 9. Swiftlet Slit, just north of location A on survey. A. From front entrance. B. Looking directly up the slit; phreatic scalloping on left, apse flutes on right, swiftlet nests are the brown colour on flatter parts of ceiling. C. Side profile. D. Plan of reentrant form. E. diagrammatic view of stages in development. 
Fig. 10. A re-entrant similar to the Swiftlet Slit but at higher elevation ( $20 \mathrm{~m}$ south of $\mathrm{D}$ on the survey). The fluted slit penetrates behind the slab in the centre of the image, which will eventually fall away widening the passage by another few metres. Note the rattan ladder for scale.

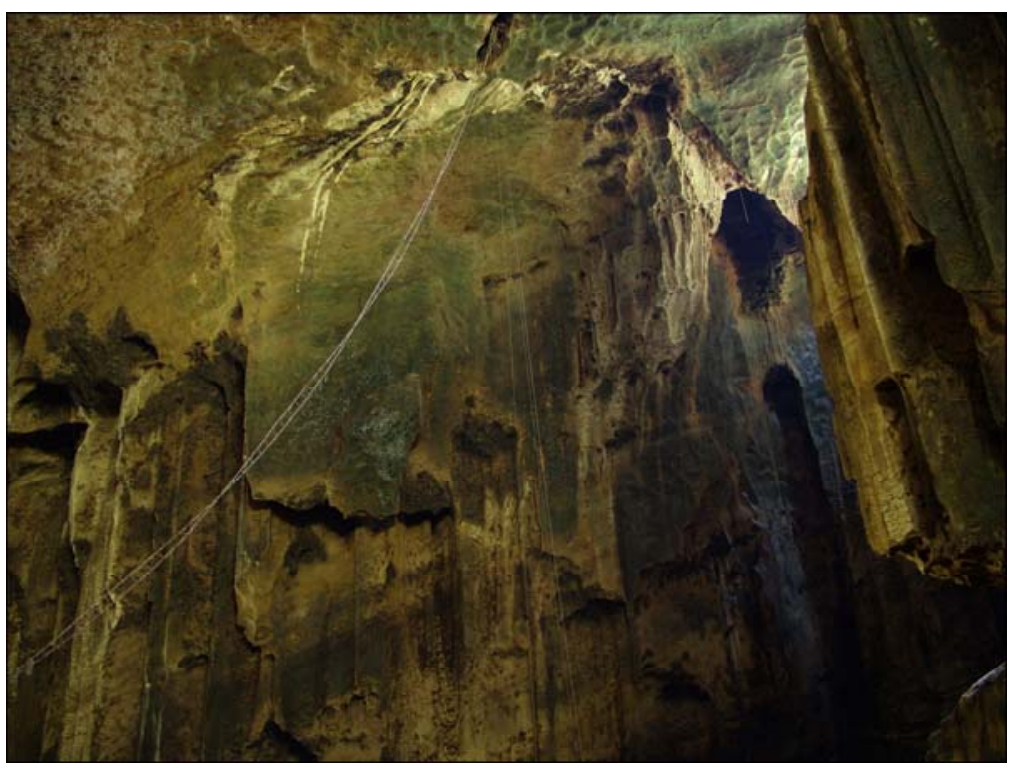

features and thus produce the broad fretting that is typical of the notch surface. This surface is quite different from the smooth, hard surface of the fresh flute and also different from the smooth concave, somewhat saprolitic surface produced by condensation corrosion (which can be seen close to entrances, e.g., in Fig 11B). The field evidence of guano notches truncating flutes, suggests that the flutes pre-date the notches (Fig. 11A).

These notches created by guanomediated corrosion are closest to the corrosion or solution notches that Jennings (1985, p.79) describes as a result of active

\subsection{Sub-cutaneous features}

The apse flutes are the dominant feature of the cave walls and conch pockets of the ceiling. However, at floor level is another type of modification, the sub-horizontal undercut notch: an example is seen in Fig. 3 at the base of the fluted wall at location D, and another in Fig. 5 at location E. Fig. 11 shows details of notches at location D (detail of wall of Fig. 3) and location G. The undercuts are $\sim 1.5-2 \mathrm{~m}$ tall and $\sim 0.5-1 \mathrm{~m}$ deep; they follow the line of contact of the guano and the cave wall. As discussed below, the evidence points to these being caused by guanomediated corrosion. Hence, following Jennings' (1985, p. 80) designation of the corrosional form resulting from dissolution in swampwater as "swamp slots", we have called these notches "guano notches" and they are classified as subcutaneous because they form under a guano cover.

The guano notches occur at the rock-guano contact at the foot of most of the walls, but, significantly, not at the contact of the sedimentary pile formed only of breakdown material. This suggests that corrosion caused by the subsediment dampness alone is insignificant. The guano notch forms under the guano surface and is exposed when the guano level lowers due to organic decomposition. Corrosion under the guano surface tends to etch out lithological solution in the soil against rock, resulting in curved incuts, and exposed by subsequent lowering of the soil surface. Note that both our corrosion notches and those of Jennings are inherently different in origin from the "wall notches" of Slabe (1975, p. 75) where dissolution occurs from water flowing on top of sediment, but, because the sediment protects the walls from corrosion, it is only the above-sediment wall that gets undercut. In our case the dissolution is caused by enhanced acidity in guano that is decaying in aerobic conditions. We have measured $\mathrm{pH}$ and temperature in guano of Deer Cave, Mulu, and found that decay in anaerobic conditions at $>50$ $\mathrm{cm}$ depth produces an increase in temperature but not in acidity, while shallow, well aerated conditions show a considerable increase in acidity - to $\mathrm{pH}$ levels around 3.5 but reaching as low as 2.4 (Lundberg and McFarlane, in press).

The level of the guano fill waxes and wanes with swiftlet and bat populations, with rate of decay, with extent of cementation by phosphate deposition, with mining by humans for fertilizers, and, over the long term, with base level lowering. The northeastern part of the cave shows evidence for at least one former guano level at $\sim 10 \mathrm{~m}$ above the present floor (Fig. 11B), and two notches can be seen at location $\mathrm{E}$, the upper one $\sim 2.5 \mathrm{~m}$ above present surface. 
Fig. 11. The guano notches. A. Notch at location $D$ and cross sections. B. Modern and former notch at location G. Note the hollows from normal cave entrance condensation corrosion. The wooden uprights from the handrail to the boardwalk are exactly 1 $\mathrm{m}$ high.

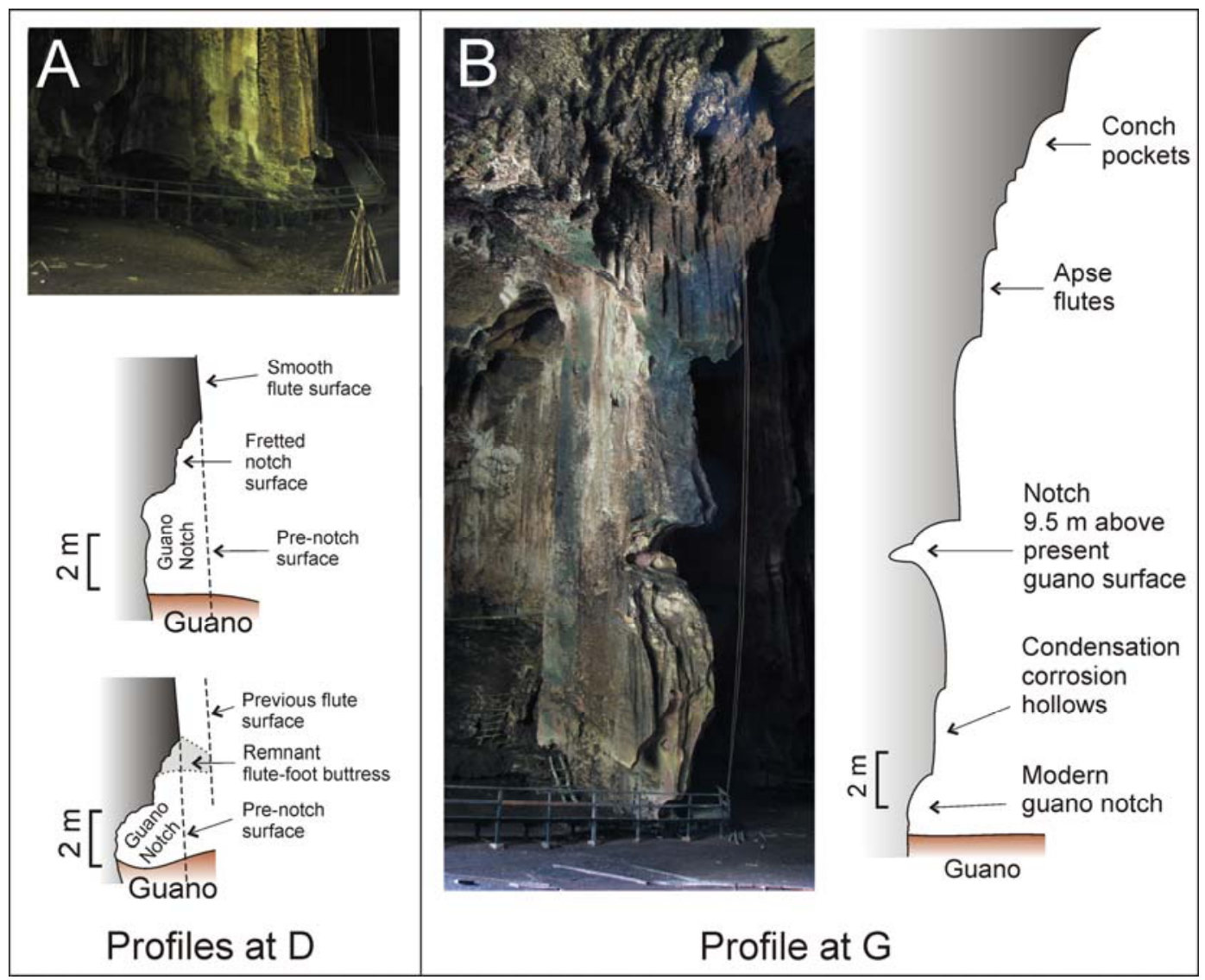

3.3. Estimate of extent of biogenic passage enlargement

Using the evidence for the original phreatic cross sections (Figs. 12 and 13) and the size of unmodified phreatic tubes in other parts of the system, we have estimated the amount of postspeleogenetic modification. The phreatic tube in Simud Hitam main chamber is $\sim 16 \mathrm{~m}$ in diameter. For Section A-A' the modern cross sectional area (above sediment only) is $\sim 420 \mathrm{~m}^{2}$; we estimate the original cross-sectional area at $\sim 240 \mathrm{~m}^{2}$, giving some $180 \mathrm{~m}^{2}$ or $75 \%$ augmentation in passage size. For section D-D' the modern passage is $\sim 940 \mathrm{~m}^{2}$; if we assume both phreatic passages at about the same size, then the original passage was $480 \mathrm{~m}^{2}$; the additional area is $\sim 460 \mathrm{~m}^{2}$ of passage or $\sim 95 \%$ augmentation. These estimates are obviously very rough but they do suggest that the modification can be substantial. It is clear that much of the enlargement is augmented by collapse of wall slabs where the fluting has cut back into the rock by headward erosion along the line of a steeply angled joint that is sub-parallel with the main passage wall; this isolates a rock slab, which then falls inwards, as seen in the Swiftlet Slit (Fig. 9). Thus the passage enlarges by a combination of direct fluting and flute-triggered collapse. So, if the total passage augmentation is of the order of $70-100 \%$, the proportion caused directly by the fluting process is perhaps $35-50 \%$ and by collapse another 35-50\%. The collapse blocks are themselves removed by the enhanced sub-cutaneous dissolution in the guano.

Estimates of the amount of modification from guano notching suggest that it is small. If we assume the guano niches to be on average $2 \mathrm{~m}$ tall and $0.75 \mathrm{~m}$ deep, then cross sectional area for each niche is $0.75 \mathrm{~m}^{2}$, representing only about $0.4 \%$ passage enlargement. This perhaps reflects the fact that deep, damp guano deposits are anaerobic and do not produce the levels of organic acids generated in aerobic conditions. 
Fig. 12. Annotated cross sections used as the basis for estimation of extent of passage modification. The original phreatic tube can be seen at A-A', with asymmetric current scalloping. This tube can also be followed closer to the cave entrance. The upper level phreatic tube shown in section DD' is traced from the roof and also from other phreatic tubes evident in this region

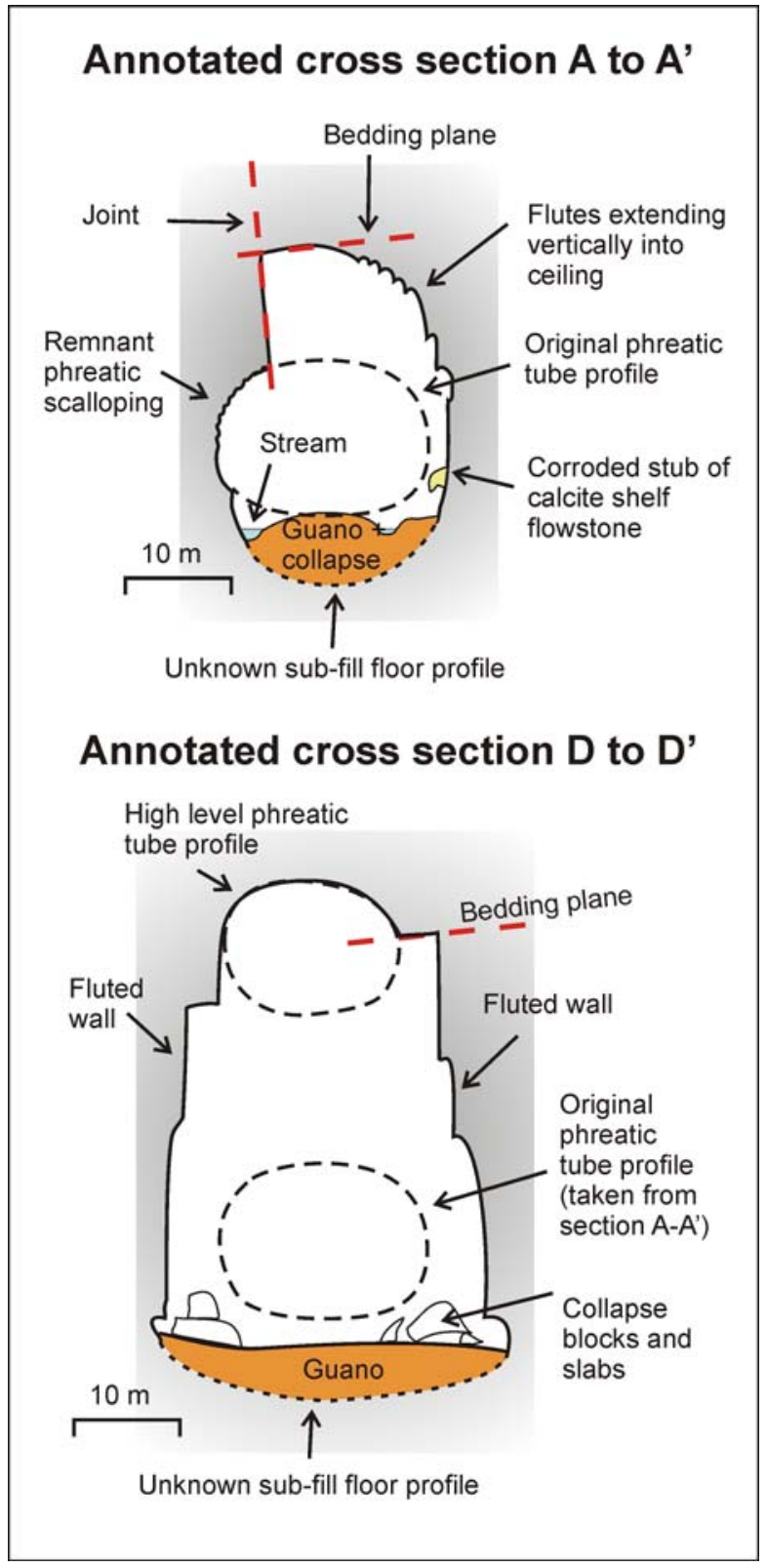

\section{Modelling}

In order to model the potential impact of metabolic activity on dissolution, we estimated the output of $\mathrm{CO}_{2}, \mathrm{H}_{2} \mathrm{O}$ vapour, and heat from the bats and birds. Results are shown in Table 2.

\subsection{Temperatures}

Temperatures (1 SD range) of various surfaces $\left(8^{\text {th }}\right.$ August 2008) are shown in Fig. 14 and Table 1 . Walls show the lowest temperature at $25.55 \pm 0.37^{\circ} \mathrm{C}$; the roof of the open cave passage, without swiftlets or bats is $26.18 \pm 0.08^{\circ} \mathrm{C}$; floors are made of guano, whose slightly higher temperature of $26.53 \pm 0.34^{\circ} \mathrm{C}$ suggests decay; the roof with birds is again a little higher at 27.02 \pm 0.76 . These four temperatures are all within $\sim 1.5^{\circ} \mathrm{C}$. However, the temperature of the roof aven, where circulation is limited, is 30.42 $\pm 0.63^{\circ} \mathrm{C}$, more than $4^{\circ} \mathrm{C}$ higher than the rest. One way ANOVA (using the on-line calculator at http://faculty.vassar.edu/lowry/anova1u.html) indicates that the roof without bats/birds is not significantly warmer than the walls or the floor, that the roof with birds is significantly warmer than the walls and the roof without birds, and that the aven is significantly warmer than all other sites.

Meteorological data are not available for Gomantong. The closest station is Sandakan, $118.06^{\circ} 5.90^{\circ} 13 \mathrm{~m}$ asl, $30 \mathrm{~km}$ to the northwest of Gomantong, for which data are readily available only from $\sim 1985$ to 1997 . Mean annual temperature for Sandakan is $26.94 \pm 0.68^{\circ} \mathrm{C}$ and the Gomantong Cave wall temperature, although $1.4^{\circ} \mathrm{C}$ cooler, is not significantly different from this $(p=0.3)$. However, it is likely that the wall temperature is actually a better estimate for mean annual temperature of Gomantong. Sandakan, being on the coast and lacking the thick primary forest cover of Gomantong, is probably warmer than Gomantong: field measurements at the Danum Valley (94 km southwest of Gomantong) found that air temperature in primary forest was $3.4^{\circ} \mathrm{C}$ lower than secondary forest (Porter, 2010).

Data on average time for foraging $\mathrm{v}$. roosting of both birds and bats are limited. Novick (1959) observed birds leaving and entering but did not record the times, other than to suggest dawn and dusk. Tourist information websites (e.g., http://www.wildasia.org/main.cfm/library/Gomant ong_Caves) indicate that birds often return about 17:15-18:15 hours. Fullard et al. (1993) observed 
swiftlets on Atiu, Cook Islands, leaving at 6.15$7.30 \mathrm{am}$ and returning at 18:00-19:15 hours (i.e., they remained in the cave for 11-13.5 hours). We therefore used a 12 hour day for the birds. This is likely a conservative estimate since we observed that many adult birds remained in the cave by day and they are less likely to emerge on rainy days. For bats, the limited literature suggests a generally longer roost time than 12 hours. Jones and Rydall (1994) indicate that most bats emerge within an hour of local sunset. However we found few data on times that bats return. Time spent foraging varies with time of year, weather, day length, sex, reproductive conditions, risk from predators (Barclay, 1989) and moonlight (Morrison, 1978). Morrison (1978) timed bats emerging 30-40 minutes after local sunset and returning 30-40 minutes before sunrise (approximately 13 hours of roosting) - but this applied only to normal days; they remained in roost for longer for the week around full moon. Kalko et al. (1999) studied two species of Neotropical bat in Panama, with varying results, but only a few were tracked throughout the night. The few data on hours spent outside include: $8 \mathrm{hr}, 5.5 \mathrm{hr}$, and 4-8.7 hours outside (i.e., some 17.5 hours inside). Time spent outside was less around full moon and during heavy rain. Barclay (1989) observed foraging times of 5-7 hours for female Lasiurus cinereus bats (i.e., by implication, 17-19 hours roosting). We therefore assume an 18 hour day for bat roosting.

Fig. 13. Simud Hitam, looking from the main passage towards entrance. The remnant intact phreatic surface with asymmetric current scallops can be seen to the left and centre (marked "s").

Fig. 14. Temperatures of in-cave surfaces, $8^{\text {th }}$ August 2008 , shown as the $1 \sigma$ range.

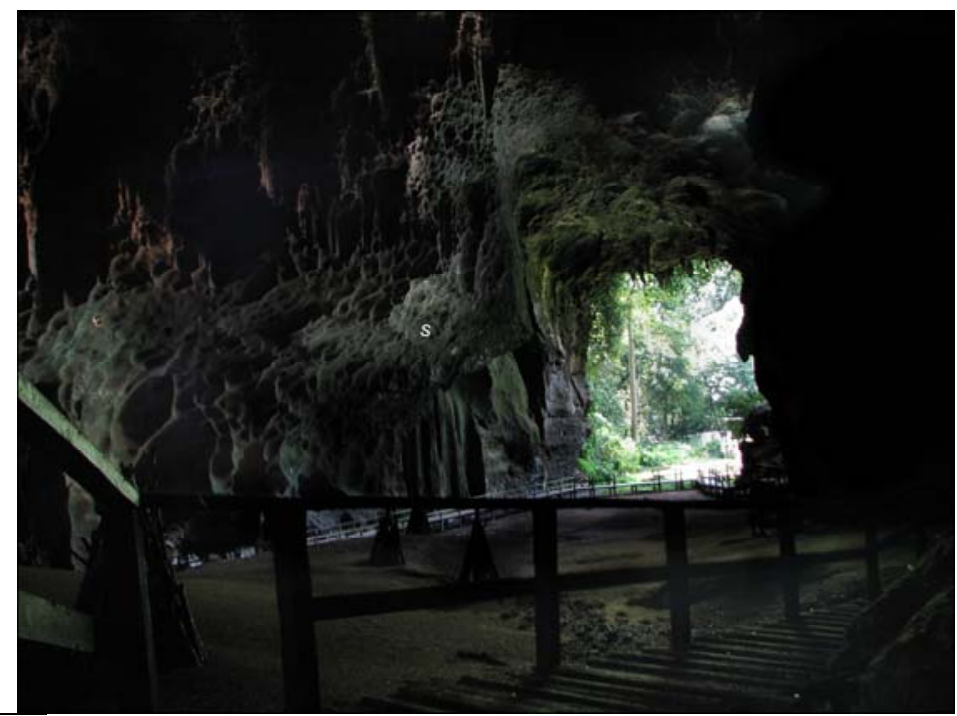

Table 1: Temperature data

\begin{tabular}{lll}
\hline Site & $\boldsymbol{n}$ & Temperature ${ }^{\circ} \mathbf{C}$ \\
\hline Walls & 16 & $25.55 \pm 0.37$ \\
Guano floor & 12 & $26.53 \pm 0.34$ \\
$\begin{array}{l}\text { Roof without } \\
\text { birds/bats }\end{array}$ & 5 & $26.18 \pm 0.08$ \\
$\begin{array}{l}\text { Roof with swiftlets } \\
\text { Roof of aven }\end{array}$ & 6 & $27.02 \pm 0.76$ \\
\hline
\end{tabular}

ANOVA results

Between groups F statistic $=128.9, p<0.0001$

\begin{tabular}{|l|l|l|l|l|}
\hline & $\begin{array}{l}\text { Guano } \\
\text { floor }\end{array}$ & $\begin{array}{l}\text { Roof } \\
\text { without } \\
\text { birds/bats }\end{array}$ & $\begin{array}{l}\text { Roof } \\
\text { with } \\
\text { swiftlets }\end{array}$ & $\begin{array}{l}\text { Roof of } \\
\text { aven }\end{array}$ \\
\hline Walls & $<0.01$ & $\mathrm{n}$ & $<0.01$ & $<0.01$ \\
\hline Guano floor & & $\mathrm{n}$ & $\mathrm{n}$ & $<0.01$ \\
\hline $\begin{array}{l}\text { Roof } \\
\text { without } \\
\text { birds/bats }\end{array}$ & & $<0.01$ & $<0.01$ \\
\hline $\begin{array}{l}\text { Roof with } \\
\text { swiftlets }\end{array}$ & & & & $<0.01$ \\
\hline
\end{tabular}

"n" = not significantly different using Tukey HSD test http://faculty.vassar.edu/lowry/anova1u.html 
Fig. 15. Bird/bat counting site. This is an example of moderately dense occupancy, where some bare rock can be seen between nests/bats. Inset shows the black-nest swiftlet nests with a few adults in attendance (most adults are out foraging during daylight hours). The horseshow bats are identifiable by elongate shadows.

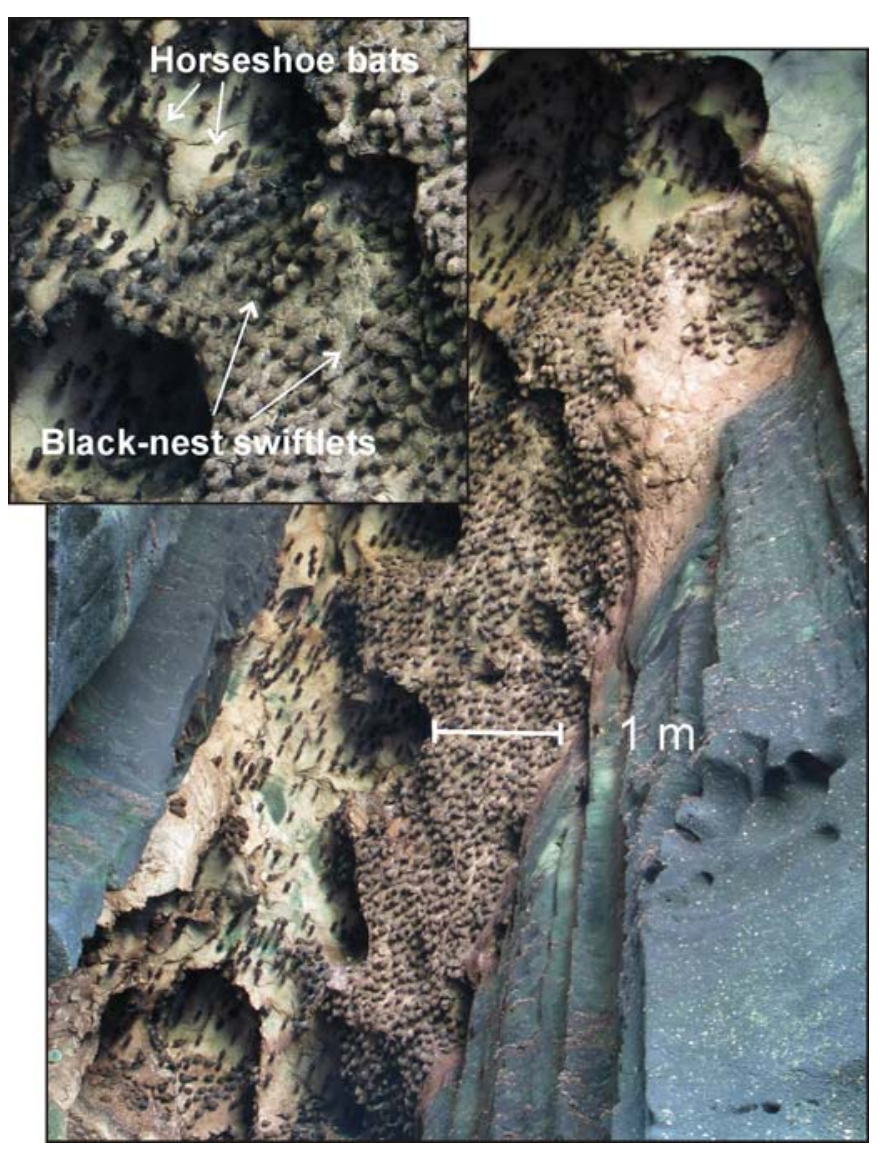

An area of roof, $19.41 \mathrm{~m}^{2}$ (Fig. 15), was chosen as a typical example of moderately dense bird/bat occupancy (at the most dense occupancy, very little bare rock can be seen between the nests or the roosting bats). This was photographed at high resolution and the numbers of nests of the black-nest swiftlet (Aerodramus maximus) and of bats (in this case they were all horseshoe bats) were counted. Each nest represents a pair of adults plus one nestling (Tompkins and Clayton, 1999). Because this cave is intensively harvested, we know that every nest is recent and occupied. Nestlings were not included in the modeling since they occupy the site only for only approximately one quarter of each year. The number of nests averaged over the $19.41 \mathrm{~m}^{2}$ area was 61.5 per $\mathrm{m}^{2}$, yielding 123 birds per $\mathrm{m}^{2}$; the number of bats was 16.6 per $\mathrm{m}^{2}$. Obviously in this example birds dominate and thus the modeling yields a higher impact from the population of birds than bats. The model was also run using different proportions of bats to birds.

Values for body mass, basic metabolic rates, and evaporative water loss were estimated from the literature. Average body mass of adult $A$. maximus is $18 \mathrm{~g}$ (range 14 to $21 \mathrm{~g}$ : Koon and Cranbrook, 2002). The bats in the sample plot are all horseshoe bats, but the cave houses a great variety of bats. Of the horseshoe bats, $R$. philippinensis, $R$. borneensis and $R$. creaghi are common in Gomantong Caves, with an average body mass of $\sim 10 \mathrm{~g}$, the value used initially for modeling. However, the most common bat in the cave is the larger, wrinkle-lipped bat, Chaerophon plicata, with typical body mass of $15.5 \mathrm{~g}$ (Leelapaibul et al., 2005). In addition to being larger, the wrinkle-lipped bat typically has a more dense roosting pattern. C. plicata is closely related to the North American Tadarida brasiliensis which is of similar size and general habits; $T$. brasilienis (and also C. plicata) roosts in dense mats on the roofs of caves. Densities of very similar roosting aggregations of $T$. brasiliensis are 1550 individuals $/ \mathrm{m}^{2}$ (Fraze and Wilkins, 1990). These differences between the horseshoe bats of the sample plot and the more common wrinklelipped bat imply that our model may be quite conservative, so we also ran it with wrinkle-lipped bats at the same density as the horseshoe bats, and then, to model a more extreme situation, with no birds and wrinkle-lipped bats at a density of 500 individuals per $\mathrm{m}^{2}$.

Metabolic rate is quoted either as energy expenditure, in $\mathrm{kJ} / \mathrm{g}$ bird/hr, or in $\mathrm{O}_{2}$ expenditure, in $\mathrm{ml} \mathrm{O}_{2} / \mathrm{g} / \mathrm{hr}$, the conversion varying slightly with type of food (e.g., Helversen and Reyer, 1984; Thomas et al., 1984): a typical value for insectivores is $4.804 \mathrm{kcal} /$ litre (Webb et al., 1992). Data on basic metabolic rate (BMR) are not available for either of the two species of swiftlet in Gomantong, so values were estimated from data on similar species. Basic metabolic rates for insectivorous birds and swiftlets are given in Bryant and Hails (1983), Bryant and Tatler (1990), and McNab and Bonaccorso (1995). We used the average values for swiftlets, $2.248 \mathrm{ml}$ $\mathrm{O}_{2} / \mathrm{g} / \mathrm{hr}$, in the modeling (if the average value for all the insectivorous birds is used, the final outcome varies by only $\sim 0.3 \%$ ). Basic metabolic rates for various bats are given in McNab (1969) 
and Hayssen and Lacy (1985). These vary greatly with bat ecology and physiology (e.g., hibernation). We used $2.89 \mathrm{ml} \mathrm{O}_{2} / \mathrm{g} / \mathrm{hr}$ (Fleming, 1988), a typical value for small omnivorous tropical bats (again, the final outcome does not vary greatly if this number is lower, say 2.0 instead of 2.89).

Evaporative water loss (EWL) is quoted in g $\mathrm{H}_{2} \mathrm{O}$ /day, which can be expressed as an average value per hour, and varies with activity levels (e.g., Engel et al., 2006). Water loss estimates for various birds at rest are given by Ro and Williams (2010). We used the average value for birds of body mass 18 g: $2.26 \mathrm{mg} \mathrm{H}_{2} \mathrm{O} / \mathrm{g} / \mathrm{hr}$. Bats, especially small ones with high surface area to volume ratio, lose a lot of water (Ho and Lee, 2003). For example, the EWL measured on adult Myotis lucifugus (body mass: 9-10 g) is $\sim 6.3 \mathrm{mg} / \mathrm{g}$ $/ \mathrm{hr}$ at $30^{\circ} \mathrm{C}$ (Studier and O’Farrell, 1976). Studier (1970) gives EWL for bats (in $\mathrm{g}_{2} \mathrm{O}$ averaged over 24 hours) as: Log of Evaporative Water loss $=\operatorname{Ln}(0.398)+0.672 * \operatorname{Ln}($ bat mass) which yields 7.9 $\mathrm{mg} \mathrm{H}_{2} \mathrm{O} / \mathrm{g} / \mathrm{hr}$ for bats mass of $10 \mathrm{~g}$, the value we used for modelling.

Expenditure of $\mathrm{O}_{2}$ (basic metabolic rate) also gives output of $\mathrm{CO}_{2}$ since $\mathrm{O}_{2}$ input equals

\subsection{Estimates of erosion rate}

During dissolution of $\mathrm{CaCO}_{3}$ for every molecule of $\mathrm{CO}_{2}$ converted into $\mathrm{H}_{2} \mathrm{CO}_{3}$ a molecule of $\mathrm{CaCO}_{3}$ is released. For very thin water films, up to $0.05 \mathrm{~mm}$, where water is either stagnant or has laminar flow, $\mathrm{CO}_{2}$ conversion to carbonic acid $\mathrm{H}_{2} \mathrm{CO}_{3}$ is dissolution-rate limiting (for thicker films diffusion and then mass transport are the limiting factors) (Dreybrodt, 2004). Equilibrium concentration of $\mathrm{Ca}$ (with respect to calcite) therefore depends on the $\mathrm{CO}_{2}$ concentration in the solution. We can estimate dissolution rate in two ways.

Dissolution of $\mathrm{CO}_{2}$ in the water film is the limiting step. The production of $\mathrm{CO}_{2}$ (134 $\mathrm{g}$ $\mathrm{CO}_{2} / \mathrm{m}^{2}$ /day from both bats and birds) is considerably higher than the solubility of $\mathrm{CO}_{2}$ (at $30^{\circ} \mathrm{C}$ : 0.1257 grams $\mathrm{CO}_{2}$ per $100 \mathrm{ml} \mathrm{H}_{2} \mathrm{O}$ ). Since production of $\mathrm{CO}_{2}$ is in excess, dissolution rate is controlled by the amount of exhaled water. The maximum amount of $\mathrm{CO}_{2}$ that can be dissolved in the $83 \mathrm{~g} \mathrm{H}_{2} \mathrm{O} / \mathrm{m}^{2} /$ day exhaled by birds and bats is
$\mathrm{CO}_{2}$ output by volume, or it can be expressed by weight. The result for birds is $40.46 \mathrm{ml}$ $\mathrm{CO}_{2} / \mathrm{bird} / \mathrm{hr}$ or $0.0795 \mathrm{~g} \mathrm{CO}_{2} / \mathrm{bird} / \mathrm{h}$. So the $2214 \mathrm{~g}$ of bird on $1 \mathrm{~m}^{2}$ of roof will produce $\sim 117 \mathrm{~g} \mathrm{CO}_{2}$ per day (i.e., one12 hour roost period - this is a conservative estimate because not all adults leave the cave by day while nesting and the nestlings remain in the cave for some 28 days, three times a year). The bats produce $\sim 16 \mathrm{~g} \mathrm{CO}_{2}$ per day.

A side effect of metabolism is the expenditure of energy: $0.058 \mathrm{~kJ} / \mathrm{g} / \mathrm{hr} \quad(165$ $\mathrm{kJ} / \mathrm{m}^{2} /$ day) for bats and $0.045 \mathrm{~kJ} / \mathrm{g} / \mathrm{hr}$ (or 1201 $\mathrm{kJ} / \mathrm{m}^{2} /$ day) for birds. Since the energy required to raise the volume of air in the aven by $4^{\circ} \mathrm{C}$ is 281 $\mathrm{kJ}$, this is more than adequate to explain the significantly higher temperatures in the aven compared to the open cave. The functional effect of the high temperatures is to ensure that exhaled moisture and $\mathrm{CO}_{2}$ remain trapped against the ceiling. It also explains why the locus of dissolution remains vertical regardless of lithological variations.

$0.105 \mathrm{~g} / \mathrm{m}^{2} /$ day or $0.0024 \mathrm{moles} / \mathrm{m}^{2} /$ day. Dissolution of $\mathrm{CaCO}_{3}$ is thus 0.0024 moles or $0.238 \mathrm{~g} \mathrm{CaCO}_{3} / \mathrm{m}^{2} /$ day (molecular weight 100 ) or $9.54 \times 10^{-5} \mathrm{~mm} \mathrm{CaCO}_{3}$ /day over the $\mathrm{m}^{2}$ area. This then gives an estimate of an erosion rate of 34.8 $\mathrm{mm} / \mathrm{ka}$ (or $1 \mathrm{~m}$ of erosion in $\sim 30,000$ years). This serves as a maximum rate since in reality dissolution of $\mathrm{CO}_{2}$ depends on the partial pressure and is unlikely to be at its maximum, due to diffusion into the greater air mass of the cave.

The second way of estimating potential erosion rate takes partial pressure into account. Using the volume of biogenic $\mathrm{CO}_{2}$ produced and the volume of air into which it is presumed to dissipate, we can calculate the partial pressure of $\mathrm{CO}_{2}$ and the corresponding concentration of $\mathrm{CaCO}_{3}$ of the water film under open dissolution conditions (Dreybrodt, 1999). The exhaled $\mathrm{CO}_{2}$ is released along with the warm water vapour very close to the rock surface. If we assume that the $\mathrm{CO}_{2}$ collects within the uppermost metre of the aven, then bat exhalation contributes PCO2 of 0.008 atmospheres and bird exhalation a further 
PCO2 of 0.060 atm. for a total of 0.068 atm. which corresponds to $400 \mathrm{ppm} \mathrm{CaCO}_{3}$ (using Dreybrodt's, 1999, graphs). This yields $33 \mathrm{mg}$ $\mathrm{CaCO}_{3} / \mathrm{m}^{2} /$ day or $4.6 \mathrm{~mm} / \mathrm{ka}$ or $1 \mathrm{~m}$ of erosion in $\sim 220,000$ years.

However, for a more conservative estimate we might assume that the volume of $\mathrm{CO}_{2}$ is instead dissipated evenly throughout the trapped air of the aven. Bat exhalation contributes $\mathrm{PCO}_{2}$ of 0.002 atmospheres and bird exhalation a further $\mathrm{PCO}_{2}$ of $0.015 \mathrm{~atm}$. for a total of $0.017 \mathrm{~atm}$. which corresponds to $260 \mathrm{ppm} \mathrm{CaCO}_{3}$. This yields $21.7 \mathrm{mg} \mathrm{CaCO}_{3} / \mathrm{m}^{2} /$ day or $3.0 \mathrm{~mm} / \mathrm{ka}$ or 1 $\mathrm{m}$ of erosion in $\sim 330,000$ years.

The bat species makes only a little difference to the outcome. If we replace horseshoe bats with wrinkle-lipped bats (higher body mass) the estimate of erosion at $400 \mathrm{ppm}$ is $5 \mathrm{~mm} / \mathrm{ka}$ or $1 \mathrm{~m}$ in 200,000 years and at $260 \mathrm{ppm}$ is 3.3 $\mathrm{mm} / \mathrm{ka}$ or $1 \mathrm{~m}$ in 305,000 years.

The proportion of bats to birds makes a slight difference to the outcome because bats have higher water losses than birds. The balance in the example is close to $75 \%$ birds and $25 \%$ bats; if we swap this ratio then erosion is a little faster (at 400 ppm: $1 \mathrm{~m} / \sim 180,000$ years; at 260 ppm: 1 $\mathrm{m} / 280,000$ years).

\section{Discussion}

The apse flutes and conch pockets are probably not unique to this cave (e.g., Wilford, 1964, reports similar but smaller ones from Niah Cave) but they are probably the largest and best developed. Other than Wilford's (1964) account, these types of flutes have not been reported in the literature, although we suspect that the huge "bellholes" that Ford and Williams (2007, p. 265) observed in some very large tropical cave entrances ( $~ 8 \mathrm{~m}$ in height and $1.5 \mathrm{~m}$ in diameter but cut and exposed to view by condensation corrosion) are probably apse flutes.

The flutes were remarked upon many times by Wilford (1964) and caused him some consternation because of his inability to come to a satisfactory conclusion about their mode of formation. He failed to account for them using all available phreatic/vadose theories: they are not asymmetric as would be expected of phreatic features; no source of vadose water or evidence of
The most important control is density of biomass. If we use only wrinkle-lipped bats at a density of 500 individuals $/ \mathrm{m}^{2}$, then erosion is significantly faster. At $400 \mathrm{ppm}$ it is $52 \mathrm{~mm} / \mathrm{ka}$ or $1 \mathrm{~m}$ in 20,000 years; at $260 \mathrm{ppm}$ it is $34 \mathrm{~mm} / \mathrm{ka}$ or $1 \mathrm{~m}$ in 30,000 years.

In summary the estimates of erosion rate range from the more conservative estimate of $1 \mathrm{~m}$ in $~ 300,000$ years to the maximum rate of $1 \mathrm{~m}$ in $\sim 20,000$ years. Even the most conservative estimate allows considerable modification of the cave passage within Quaternary time scales. In general we have erred on the conservative side. We chose a site with only moderate densities of colonization. In addition, the number of organisms today is likely to significantly under-represent the populations of the past, due to heavy anthropogenic disturbance in historic times (e.g., Hobbs, 2004). The bats/birds are not distributed evenly throughout the cave - rather they are clumped in favorable sites. The result is that biogenic passage modification is focused only in certain zones within the cave. Some parts of the cave can thus remain with barely altered original phreatic scalloping.

flowing water can be seen; they do not appear to originate from water falls or water films held to the rock by surface tension (they pass upwards into water-tight cavities in the ceiling); and he discounts abrasional potholes in the ceiling as highly improbable. Eventually he offers the suggestion that, in spite of the absence of erosion along joints or bedding planes, the only explanation left is convectional currents in very stable phreatic water - but with occasional floods providing swirling waters to create the ceiling pockets.

Our observations suggest that these are neither vadose nor phreatic features. They develop in the absence of flowing water. We suggest that they result from a highly specialized form of biogenically-mediated condensation corrosion as a direct result of the large populations of bats and birds.

The apse flutes and conch pockets have obvious affinities with bellholes. Bell holes are also cylindrical, cigar-shaped, blind cavities 
extending vertically upwards into the roofs of caves, although they are generally less than $1 \mathrm{~m}$ in diameter and $2 \mathrm{~m}$ in height (Tarhule-Lips and Ford, 1998a, 1998b; Lundberg, 2005, Lundberg and McFarlane, 2007). Ford and Williams (2007, p. 265) regard bellholes as "a geomorphological peculiarity” because they are vertical regardless of lithological variation, stratigraphic dip, or ceiling gradient and have no association with fractures or feedwater routes. Tarhule-Lips and Ford (1998b) attribute bell holes to condensation corrosion combined with microbial activity: biofilms establish themselves in patches on ceilings in entrance zones, create an initial depression, which in turn traps the warm air, inducing extra condensation. Lundberg and McFarlane (2007) demonstrate that metabolic activity from clustering bats could plausibly create bell holes within $\sim 50,000$ years. In addition the clustering habit of the bats along with the likely habit of fidelity of bats to precise locations within roost sites (see Selvanayagam and Marimuthu, 1984) could explain the extreme localization of the corrosion.

In some respects the apse flutes have a similar morphology, although at a very much larger scale, to the extraordinary lacustrine karren described by Simms (1990) and Drew (2010) from Ireland. Tubes generally up to $\sim 5 \mathrm{~cm}$ in diameter and up to $\sim 30 \mathrm{~cm}$ deep (called "Röhrenkarren") develop on the undersides of bedding planes where rising waters, saturated with respect to calcite, trap pockets of air under rock ledges. Condensation corrosion within these isolated pockets then carves perfectly circular cigar-shaped tubes upwards into the base of the bed.

All these forms of vertically-extending tube share the same extraordinary characteristic of ignorance of rock controls and they all are produced by some form of very localized condensation corrosion that is quite distinct from the generalized cave entrance condensation corrosion that produces, typically, large air scallops (see Hill, 1987; Slabe, 1995; Ford and Williams, 2007: air scallops develop where turbulent air movements near cave entrances introduce humid air that condenses on the walls). We argue that in the case of apse-flutes the condensation is directly caused by the organisms in the cave.

Our modeling suggests that metabolic output from a relatively small population of bats and birds is more than adequate to erode a substantial volume of rock. We argue that the flutes and conch pockets are created by the presence of multitudes of swiftlets and bats over the millennia. The functional effect of the metabolic heat ensures that exhaled moisture and $\mathrm{CO}_{2}$ remain trapped against the ceiling. It also explains why the locus of dissolution remains vertical regardless of lithological variations. Our model shows that exhaled $\mathrm{CO}_{2}$ is in excess of requirements for maximum dissolution. The limiting step is the amount of exhaled $\mathrm{H}_{2} \mathrm{O}$ that can condense on the rock surface. The daily exodus of the occupants ensures a regular replacement of the air. Most sites have either bats or birds. Thus the bat sites cool down by night and the bird sites cool down by day, allowing for renewed condensation of super-saturated exhaled air.

This biogenic post-speleogenetic passage modification appears to be a substantial process for these caves, sometimes even doubling passage size, at least for those passages with long-term bat/bird occupancy. We show our interpretation in diagrammatic form in Fig. 16. The original rounded phreatic form is modified by development of vertical apse flutes of many generations forming nested hierarchies of flutes of different ages. These propagate mainly vertically upwards, raising the ceiling, and to a lesser extent laterally, steepening and extending the walls. The end result is a passage with little evidence of its phreatic origin.

The absence of any obvious point source of moisture is explained by the presence of a ubiquitous film of condensation moisture. Although no flow features can be seen, many of the apse flutes show the pattern of diminution with distance downslope that indicates loss of aggressivity of solvent and confirms that the locus of maximum dissolution is towards the ceiling. Those flutes that do not show this diminution from ceiling to floor invariably have rougher surfaces that catch guano and feathers. This thin coating of decaying organic matter acts to renew 
aggresssivity downslope. Thus these flutes represent modified apse flutes.

In cross section the only cases where the form is deeper than the simple semi-circular arc is where a swiftlet nest is lodged on a ledge (which is quite rare - the majority of birds simply build nests directly on rock surface regardless of angle).
Then the guano does not fall straight to the ground; instead a guano-rich dark-coloured liquid/solid mixture flows down the centre of the flute incising it into a deep and highly fretted $\mathrm{V}$ shape (these are a type of decantation flute; we call them "copragenic flutes" because of the intimate association with guano).

Fig. 16. Diagrammatic view of biogenic post-speleogenetic modification of original phreatic tube by development of many generations of apse flutes and their associated conch pockets. The passage is enlarged in height and in width. Sub-sedimentary modifications are not included here.

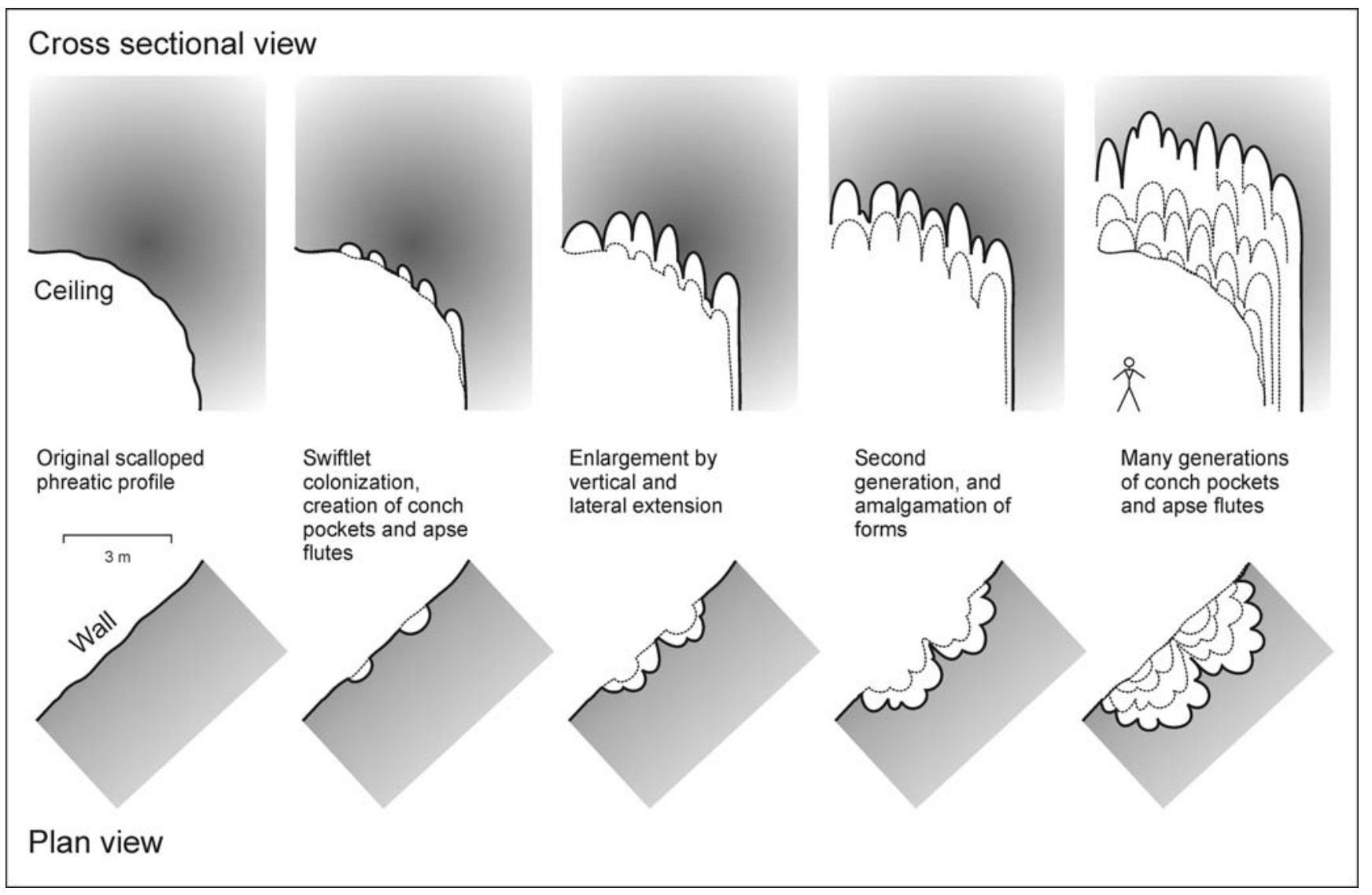

\section{Conclusion}

The caves of Gomantong, originally simple phreatic tube passages, show evidence of considerable modification attributable to biogenic activity. The post-speleogenetic biogenic modifications include both sub-aerial and subcutaneous forms. The sub-aerial forms are dramatic, previously undescribed floor to ceiling apse flutes and their associated ceiling conch pockets. These are semicircular in cross-section, $\sim 80 \mathrm{~cm}$ wide, vertical regardless of rock properties, and developed in parallel but apparently completely independent of each other.
They form by biogenically-mediated corrosion during millennia of colonization by swiftlets and bats, without an extraneous water source and without significant influence of bedding or lithology. The dominant sub-cutaneous form is the guano notch, superficially resembling fluvial notches but formed by organic acid dissolution of bedrock in direct contact with large deposits of bat and bird guano on the cave floor.

Basic modelling of the metabolic outputs from bats and birds $\left(\mathrm{CO}_{2}, \mathrm{H}_{2} \mathrm{O}\right.$, heat) reveals that post-speleogenetic biogenic corrosion can erode bedrock by between $\sim 3.0 \mathrm{~mm} / \mathrm{ka}$ (1 $\mathrm{m}$ in $300 \mathrm{ka}$ ) and $\sim 4.6 \mathrm{~mm} / \mathrm{ka}$ (1 $\mathrm{m}$ in $200 \mathrm{ka})$. Modelling at 
high bat densities yields corrosion rates of $\sim 34$ $\mathrm{mm} / \mathrm{ka}$ (or $1 \mathrm{~m}$ in $30 \mathrm{ka}$ ).

Speleogenetic assessment of the Gomantong lower cave suggests that as much as $70-95 \%$ of the total volume of the modern cave may have been opened by direct subaerial biogenic dissolution and biogenically-induced collapse and sub-cutaneous removal of limestone over a timescale of 1-2 myr. Given the scale of the resulting cave, the importance of the site to tourism and the edible-birds' nest industry, and the likely importance of similar biogenic processes in other tropical caves around the World, we suggest that secondary biospeleogenesis will prove to be a fruitful area of future research.

Table 2: Summary results of modeling using numbers and species as recorded in the sample plot.

A. Model results from birds (at $123 / \mathrm{m}^{2}$ ) and horseshoe bats (at $16.6 / \mathrm{m}^{2}$ )

\begin{tabular}{|c|c|c|c|}
\hline & Bats & Birds & Combined \\
\hline $\mathrm{CO}_{2}$ production in $\mathrm{g} \mathrm{CO}_{2} / \mathrm{m}^{2} /$ day & 17.00 & 117.32 & 134.32 \\
\hline Water loss in litres $\mathrm{H}_{2} \mathrm{O} / \mathrm{m}^{2} /$ day & 0.023 & 0.060 & 0.083 \\
\hline Heat production in $\mathrm{kJ} / \mathrm{m}^{2} /$ day & 174 & 1201 & 1375 \\
\hline Water film thickness in $\mathrm{mm}$ & 0.023 & 0.060 & 0.083 \\
\hline $\mathrm{cc}$ of $\mathrm{CaCO}_{3}$ dissolved $/ \mathrm{m}^{2}$, using $\mathrm{CO}_{2}$ output values & 0.027 & 0.069 & 0.095 \\
\hline Surface erosion in mm/yr using $\mathrm{CO}_{3}$ & 0.0097 & 0.0251 & 0.0348 \\
\hline Surface erosion in $\mathrm{mm} / \mathrm{ka}$ & 9.7355 & 25.0874 & 34.8229 \\
\hline Years required for $1 \mathrm{~m}$ of erosion using maximum dissolution of $\mathrm{CO}_{2}$ & & & 28,717 \\
\hline
\end{tabular}

A1. Assuming $\mathrm{CO}_{2}$ remains within $1 \mathrm{~m}$ of roof

\begin{tabular}{lccc}
\hline $\mathrm{cm}^{3}$ of $\mathrm{CaCO}_{3}$ dissolved $/ \mathrm{m}^{2}$, using water film thickness and & 1.286 & 3.314 & 4.600 \\
saturation at $400 \mathrm{ppm}$ & 0.0013 & 0.0033 & 0.0046 \\
Surface erosion in mm/yr using water film thickness & 1.2859 & 3.3136 & 4.5994 \\
Surface erosion in mm/ka using water film thickness & \multicolumn{3}{c}{217,419} \\
\hline Years required for $1 \mathrm{~m}$ of erosion using water film thickness @ 400 ppm
\end{tabular}

A2. Assuming $\mathrm{CO}_{2}$ diffuses throughout the $4 \mathrm{~m}$ tall aven

$\mathrm{cm}^{3}$ of $\mathrm{CaCO}_{3}$ dissolved $/ \mathrm{m}^{2}$, using water film thickness and saturation at $260 \mathrm{ppm}$

Surface erosion in $\mathrm{mm} / \mathrm{yr}$ using water film thickness

Surface erosion in $\mathrm{mm} / \mathrm{ka}$ using water film thickness

\begin{tabular}{rcc}
0.836 & 2.154 & 2.990 \\
0.0008 & 0.0022 & 0.0030 \\
0.8358 & 2.1538 & 2.9896 \\
\hline & 334,491 \\
\hline
\end{tabular}

Years required for $1 \mathrm{~m}$ of erosion using water film thickness @ $260 \mathrm{ppm}$

\begin{tabular}{ll}
\hline Years required for $1 \mathrm{~m}$ of erosion using water film thickness @ 400 ppm & 198,422 \\
\hline Years required for $1 \mathrm{~m}$ of erosion using water film thickness @ 260 ppm & 305,264 \\
\hline
\end{tabular}

C. Model results from 0 birds and wrinkle-lipped bats at densities of $500 / \mathrm{m}^{2}$

\begin{tabular}{ll}
\hline Years required for $1 \mathrm{~m}$ of erosion using water film thickness @ $400 \mathrm{ppm}$ & 19,289 \\
\hline Years required for $1 \mathrm{~m}$ of erosion using water film thickness @ 260 ppm & 29,675 \\
\hline
\end{tabular}




\section{Acknowledgements}

Funding was provided in part by a faculty research grant from Scripps College.( + Referees)

\section{References}

Abdullah, M.T., Paul, I.V., and Hall, L., 2005. A frightful stairway. Bats Magazine 23 (3), 11-13.

Abdullah, M.T., Halls, L.S., Tissen, O.B., 2007. The large bat caves of Malaysian Borneo. Bat Research News 48, 99-100.

Barclay, R.M.R., 1989. The effect of reproductive condition on the foraging behavior of female hoary bats, Lasiurus cinereus. Behavioural Ecology and Sociobiology, 24, 31-37.

Bryant, D.M., Hails, C.J., 1983. Energetics and growth patterns of three tropical bird species. The Auk, 100, 425-439.

Bryant, D.M., Tatner, P., 1990. Hatching asynchrony, sibling competition and siblicide in nestling birds: studies of swiftlets and bee-eaters. Animal Behaviour, 39, 657-671.

Chasen, F.N., 1931a. Report on the "birds' nest" caves and industry of British North Borneo with special reference to Gomantong caves. Government Printing Office, Jesselton, North Borneo.

Chasen, F.N., 1931b. On bats from the limestone caves of North Borneo. Bulletin of the Raffles Museum 5,107-114.

Collins, J.S.H., Lee, C., Noad, J., 2003. Miocene and Pleistocene crabs (Crustacea, Decapoda) from Sabah and Sarawak. Journal of Systematic Palaeontology 1, 87226.

Couzens, D., 2008. Top 100 birding sites of the World. University of California Press.

Csorba, G., Ujhelyi P., Thomas N., 2003. Horseshoe bats of the World. Alana Books. Bishop's Castle.

Dawkins, R., 2004. Extended phenotype - but not too extended. A reply to Laland, Turner and Jjablonka. Biology and Philosophy 19, 377-396.
Drew, D.P., 2010. Coastal and Lacustrine Karren in Western Ireland. In: Ginés, A., Knez, M., Slabe, T., Dreybrodt, W. (Eds.), Karst Rock Features - Karren Sculpturing. Carstologia 9, Založba ZRC / ZRC Publishing, Ljubljana, pp. 503-512.

Dreybrodt, W., 1999. Chemical kinetics, speleothem growth and climate. Boreas, 28, 47-356.

Dreybrodt, W., 2004. Dissolution: Carbonate rocks. In: Gunn, J. (Ed.), Encyclopedia of Caves and Karst Science. Fitzroy Dearborn, pp. 298.

Engel, S., Suthers, R.A., Biebach, H, Visser, G.H., 2006. Respiratory water loss during rest and flight in European Starlings (Sturnus vulgaris). Comparative Biochemistry and Physiology - Part A, 145, 23-432.

Farrant, A.R., Smart, P.L., Whitaker, F.F., Tarling, D.H., 1995. Long-term Quaternary uplift rates inferred from limestone caves in Sarawak, Malaysia. Geology 23, 257-360

Fleming, T.H., 1988. The short-tailed fruit bat. A study in plant-animal interactions. University of Chicago Press.

Ford, D.C., Williams, P.W., 2007. Karst hydrogeology and geomorphology. Wiley.

Francis, C.M., 1987. The management of edible birds' nest caves in Sabah. Sabah Forestry Department, Sandakan.

Francis, C. M., Hill, J. E., 1998. New records and a new species of Myotis (Chiroptera, Vespertilionidae) from Malaysia. Mammalia 62, 241-252.

Fraze, R.K., Wilkins, K.T., 1990. Patterns of Use of Man-Made Roosts by Tadarida brasiliensis mexicana in Texas. The Southwestern Naturalist 35, 261-267.

Fullard, J.H., Barclay, R.M.R., Thomas, D.W., 1993. Echolocation in Free-flying Atiu Swiftlets (Aerodramus sawtelli). Biotropica 25, 334-339.

Hayssen, V., Lacy, R.C., 1985. Basal metabolic rates in mammals: taxonomic difference in the allometry of BMR and body mass. Comparative Biochemistry and Physiology A. 81A, 741-754. 
Helversen, O.V., Reyer, H.-U., 1984. Nectar intake and energy expenditure in a flower visiting bat. Oecologia 63, 178-184.

Hill, C.A., 1987. Geology of Carlsbad Cavern and other caves in the Guadalupe Mountains, New Mexico and Texas. New Mexico Bureau of Mines and Mineral Resources Bulletin 117.

Ho, Y.-Y., Lee, L.-L., 2003. Roost Selection by Formosan Leaf-Nosed Bats (Hipposideros armiger terasensis). Zoological Science 20, 1017-1024.

Hobbs, J.J., 2004. Problems in the harvest of edible birds' nests in Sarawak and Sabah, Malaysian Borneo. Biodiversity and Conservation 13, 2209-2226.

Hutchinson, C.S., 2005. Geology of North-West Borneo: Sarawak, Brunei and Sabah. Elsevier.

Jennings, J.N., 1985. Karst Geomorphology. Oxford: Basil Blackwell.

Jones, G., Rydell, J., 1994. Foraging Strategy and Predation Risk as Factors Influencing Emergence Time in Echolocating Bats. Philosophical Transactions: Biological Sciences 346, 445-455.

Kalko, E.K.V., Friemel, D., Handley, C.O.Jr., Schnitzler, H.U., 1999. Roosting and foraging behavior of two Neotropical gleaning bats, Tonatia silvicola and Trachops cirrhosus (Phyllostomidae). Biotropica 31, 344-353.

Kingston, T., 2010. Research priorities for bat conservation in Southeast Asia: a consensus approach. Biodiversity and Conservation 19, 471-484.

Koon, L.C., Cranbrook, 2002. Swiftlets of Borneo. Builders of edible nests. Natural History Publications. Kota Kinabalu, Sabah, Malaysia. 171 p.

Lauritzen, S.E., Lundberg, J., 2000. Solutional and Erosional Morphology. In Klimchouk, A.B., Ford, D.C., Palmer, A.N. and Dreybrodt, W. (Eds.), Speleogenesis: Evolution of Karst Aquifers. National Speleological Society, Huntsville, Alabama, pp. 408-426.

Leelapaibul, W., Bumrungsri, S., Pattanawiboon, A., 2005. Diet of wrinkle-lipped free-tailed bat (Tadarida plicata Buchannan, 1800) in central Thailand: insectivorous bats potentially act as biological pest control agents. Acta Chiropterologica 7, 111-119.

Lundberg, J., McFarlane, D.A., 2007. Bats and bell holes: The microclimatic impact of bat roosting, using a case study from Runaway Bay Caves, Jamaica. Geomorphology 106, 78-85.

Lundberg, J., McFarlane, D.A., in press. Subaerial freshwater phosphatic stromatolites in Deer Cave, Sarawak - a unique geobiological cave formation. Geobiology.

Lundberg, J., 2005. Karren. In: Culver, D., White, W. (Eds.), Encyclopedia of Caves. Elsevier, Amsterdam, pp. 315-321.

McNab, B. K., 1969. The economics of temperature regulation in Neotropical bats. Comparative Biochemistry and Physiology 31, 227-268.

McNab, B.K., Bonaccorso, F.J., 1995. The energetics of Australasian Swifts, Frogmouths, and Nightjars. Physiological Zoology 68, 245-261.

Mihevc, A., Slabe, T., Sebela, S., 2004. Morphology of Caves. In: Gunn, J. (Ed.), Encyclopedia of Caves and Karst Science Fitzroy Dearborn, pp. 521-524.

Morrison, D.W., 1978. Lunar phobia in a neotropical fruit bat, Artibeus jamaicensis (Chiroptera: Phyllostomidae). Animal Behaviour 26, 852-855.

Noad, J., 2001. The Gomantong Limestone of eastern Borneo: a sedimentological comparison with the nearcontemporaneous Luconia Province. Palaeogeography, Palaeoclimatology, Palaeoecology 175, 273-302.

Novick, A., 1959. Acoustic Orientation in the cave swiftlet. Biological Bulletin 116, 497-503.

Piccini, L., Forti, P., Giulivo, I., Mecchia, M., 2007. The polygenetic caves of Cuatro Ciénegas (Coahuila, Mexico): morphology and speleogenesis. International Journal of Speleology 36, 83-92.

Porter, A., 2010. Abundance and diversity of anuran species in Danum Valley, Sabah, Borneo. The Plymouth Student Scientist 3, 34-50. 
Ro, J., Williams, J.B., 2010. Respiratory and cutaneous water loss of temperate-zone passerine birds. Comparative Biochemistry and Physiology, Part A, 156 237-246.

Rose, J., 1984. Contemporary River Landforms and Sediments in an Area of Equatorial Rain Forest, Gulong Mulu National Park, Sarawak. Transactions of the Institute of British Geographers, New Series 9, 345363.

Selvanayagam, P.F.L, Marimuthu, G., 1984. Spatial organization of roosting in the insectivorous tropical bat Hipposideros speoris. Behavioural Processes 9, 113-121.

Simms, M.J., 1990. Phytokarst and photokarren in Ireland. Cave Science 17, 131-133.

Slabe, T., 1995. Cave Rocky relief and its speleogenetical significance. Založba ZRC / ZRC Publishing, Ljubljana.

Thomas, S. P., Lust, M.R., Van Riper, H.J., 1984. Ventilation and oxygen extraction in the bat Phyllostomus hastatus during rest and steady flight. Physiological Zoology 57, 237-250.

Studier, E.H., O’Farrell, M.J., 1976. Biology of Myotis thysanodes and $M$. lucifugus (Chiroptera: Vespertilionidae). III. Metabolism, heart rate, breathing rate, evaporative water loss and general energetic. Comparative Biochemistry and Physiology 54A, 423-432.

Studier, E.H., 1970. Evaporative water loss in bats. Comparative Biochemistry and Physiology 35, 935-943.

Sweeting, M.M., Day, M.J., Ley, R.G., Woodroffe, C.D., Osmaston, H.A., 1980.
Symposium on the geomorphology of Mulu: an introduction. The Geographical Journal 146, 1-7.

Tarhule-Lips, R.F.A, Ford, D.C., $1998 b$. Condensation Corrosion in caves on Cayman Brac and Isla de Mona. Journal of Cave and Karst Studies 60, 84-95.

Tarhule-Lips, R.F.A., Ford, D.C., 1998 . Morphometric studies of bell hole development on Cayman Brac. Cave and Karst Science 25, 19-130.

Tompkins, D.M., 1999. Impact of nest-harvesting on the reproductive success of black-nest swiftlets Aerodramus maximus. Wildlife Biology 5, 33-36.

Tompkins, D.M., Clayton, D.H., 1999. Host resources govern the specificity of swiftlet lice: size matters. Journal of Animal Ecology 68, 489-500.

Waltham, A.C., Brook, D.B., 1980. Cave development in the Melinau limestone of the Mulu park, Sarawak. Geographical Journal 146, 258-266.

Waltham, T., 2004. Mulu, Sarawak. In: Gunn, J. (Ed.), Encyclopedia of Caves and Karst Science, Fitzroy Dearborn, pp. 531-533.

Webb, P. I., Speakman, J.R., Racey, P.A., 1992. Oxygen consumption and evaporation during parturition in a vespertilionid bat (Pipistrellus pipistrellus). Journal of Reproduction and Fertility 94, 525-528.

Wilford, G.E., 1964. The Geology of Sarawak and Sabah Caves. Bulletin 6, Geological Survey, Borneo Region, Malaysia. Brunei, Kuching. 